\title{
Synthesis, in silico studies, Antiprotozoal and Cytotoxic Activities of Quinoline-biphenyl Hybrids
}

\author{
Juan Carlos Coa ${ }^{1}$, Andrés Yepes ${ }^{1}$, Miguel Carda ${ }^{2}$, Laura Conesa-Milián ${ }^{2}$ \\ Yulieth Upegui ${ }^{3}$, Sara M. Robledo ${ }^{3, *}$ Wilson Cardona- $\mathrm{G}^{1, *}$
}

1. Química de Plantas Colombianas, Institute of Chemistry, Faculty of Exact and Natural Sciences University of Antioquia-UdeA, Calle 70 No. 52-21, A.A 1226, Medellín, Colombia

2. Department of Inorganic and Organic Chemistry, Jaume I University, E-12071 Castellón, Spain

3. PECET-Medical Research Institute, Faculty of Medicine, University of Antioquia-UdeA. Calle 70 No. 52-21, A.A 1226 Medellín, Colombia

\footnotetext{
*Author to whom correspondence should be addressed; e-mail: wilson.cardona1@udea.edu.co; sara.robledo@udea.edu.co; phone: +574-2196503 (S.M.R), +574-2195653 (W.C); Fax: +574-2196511 (S.M.R), +57-42330120 (W.C)
} 


\begin{abstract}
The synthesis, in silico studies, antiprotozoal and cytotoxic activities of eleven quinoline-biphenyl hybrids are described herein. The structure of the synthesized products was elucidated by a combination of spectrometric analyses. The synthesized compounds were evaluated against Plasmodium falciparum, and amastigotes forms both Leishmania (V) panamensis and Trypanosoma cruzi. Cytotoxicity was evaluated against human U-937 macrophages. Hybrid 4a showed similar activity than meglumine antimoniate and compound $\mathbf{4 b}$ exhibited an activity similar to that of benznidazole. Hybrid $\mathbf{4 k}$ showed the best activity against $P$. falciparum. Although these compounds were toxic for mammalian U-937 cells, however they may still have potential to be considered as candidates for drug development because of their antiparasite activity. In addition, molecular docking was used to determine the in silico inhibition of some of the designed compounds against PfLDH and cruzipain, two important pharmacological targets involved in antiparasitic diseases. All hybrids were docked to the three-dimensional structures of PfLDH and T. cruzi cruzipain as enzymes using AutoDock Vina. Notably, the docking results showed that the most active compounds $4 \mathbf{b}$ (CE50: 11.33 $\mu \mathrm{g} / \mathrm{mL}$ for $P$. falciparum) and $4 \mathbf{k}\left(\mathrm{CE}_{50}: 8.84 \mu \mathrm{g} / \mathrm{mL}\right.$ for $T$. cruzi) showed the highest scoring pose (7.5 and $-7.7 \mathrm{kcal} / \mathrm{mol}$, respectively). This result show a good correlation between the predicted scores with the experimental data profile, suggesting that these ligands could act as competitive inhibitors of PfLDH or T. cruzi cruzipain enzymes, respectively. Finally, in silico ADMET studies of the quinoline hybrids showed that these novel compounds have suitable drug-like properties, making them potentially promising agents for antiprotozoal therapy.
\end{abstract}

Keywords: Chagas disease; Trypanosoma cruzi; leishmaniasis Leishmania panamensis; Plasmodium falciparum; quinoline; hybrids; molecular docking, biphenyl, in silico studies 


\section{Introduction}

Protozoal diseases (PD) are a diverse group of diseases which are the cause of a significant mortality rate in various developing countries of tropical and subtropical regions. PDs include, among others, Chagas' disease (American trypanosomiasis), leishmaniasis and malaria which are caused by the parasitic protozoan of Trypanosoma cruzi (T. cruzi), Leishmania species and Plasmodium species, respectively (WHO 2018a). Human malaria is caused by at least five species of Plasmodium, the most important being P. falciparum and P. vivax (WHO 2018b). Leishmania (V) panamensis is one of the most prevalent Leishmania species involved in human cases of cutaneous leishmaniasis in Colombia and other countries in Central America (Alvar et al., 2012).

Current chemotherapies are still based on old drugs such as pentavalent antimonials (meglumine antimoniate and sodium stibogluconate), pentamidine isethionate and amphotericin B to treat cutaneous leishmaniasis (WHO 2019a); nitroaromatic compounds (benznidazole and nifurtimox) for treatment of Chagas disease (WHO 2019b) or chloroquine, amodiaquine, sulfadoxine/pyrimethamine to treat $P$. falciparum or $P$. vivax malaria, respectively. More recently new artemisinin-based combination therapy is recommended for the treatment of $P$. falciparum (WHO 2018b). Unfortunately, all of these drugs have several toxic effects on the patients that are associated with high doses and length of therapeutic schemes. Moreover, they are no longer as effective as before due to the emergence of drug resistance in the parasite, which complicates the control of these diseases (Chatelain and Ioset, 2011; Den Boer et al., 2011; Keenan and Chaplin, 2015; Fidock et al., 2004).

The quinolinic core is a structural feature of several bioactive compounds endowed with pharmacological activities such anti-mycobacterial, anti-microbial, anti-convulsant, anti-inflammatory and anti-tumor, among others (Suresh et al., 2009; Franck et al., 2004). Several compounds containing the quinolinic core also have antileishmanial, antitrypanosomal and antiplasmodial activities (Nakayama et al., 2005; Tempone et al., 2005; Dietze et al., 2001; Vieira et al., 2008; Cardona et al., 2013; Palit et al., 2009; Egan 2001). Thus, quinoline based compounds 1a and 1b (fig. 1) were evaluated against $L$. (V) panamensis and T. cruzi and they showed to be active in both parasites (Coa et al., 2017; Coa et al., 2015). Artemisinin-aminoquinoline hybrid 1c (fig. 1) showed high antiplasmodial activity which was 9-fold higher than chloroquine (Lombard et al., 2011) 
On the other hand, natural compounds containing the biphenyl moiety, such as honokiol (1d) and schisandrin C (1e) have shown many relevant biological activities (Ma et al. 2011; Chen et al. 2001). Another interesting compound is biphenyl derivative 1f, whose structure is based on that of methylglyoxal bis(guanylhydrazone). Compound $\mathbf{1 f}$ was active in vitro against several Trypanosoma species, including T. brucei rhodesiense and T. b. brucei (Brun et al. 1996). Finally, the furanchalconebiphenyl hybrid 1g, exhibited good activity against T. cruzi showing better activity than benznidazole (García et al., 2019) (fig. 1).
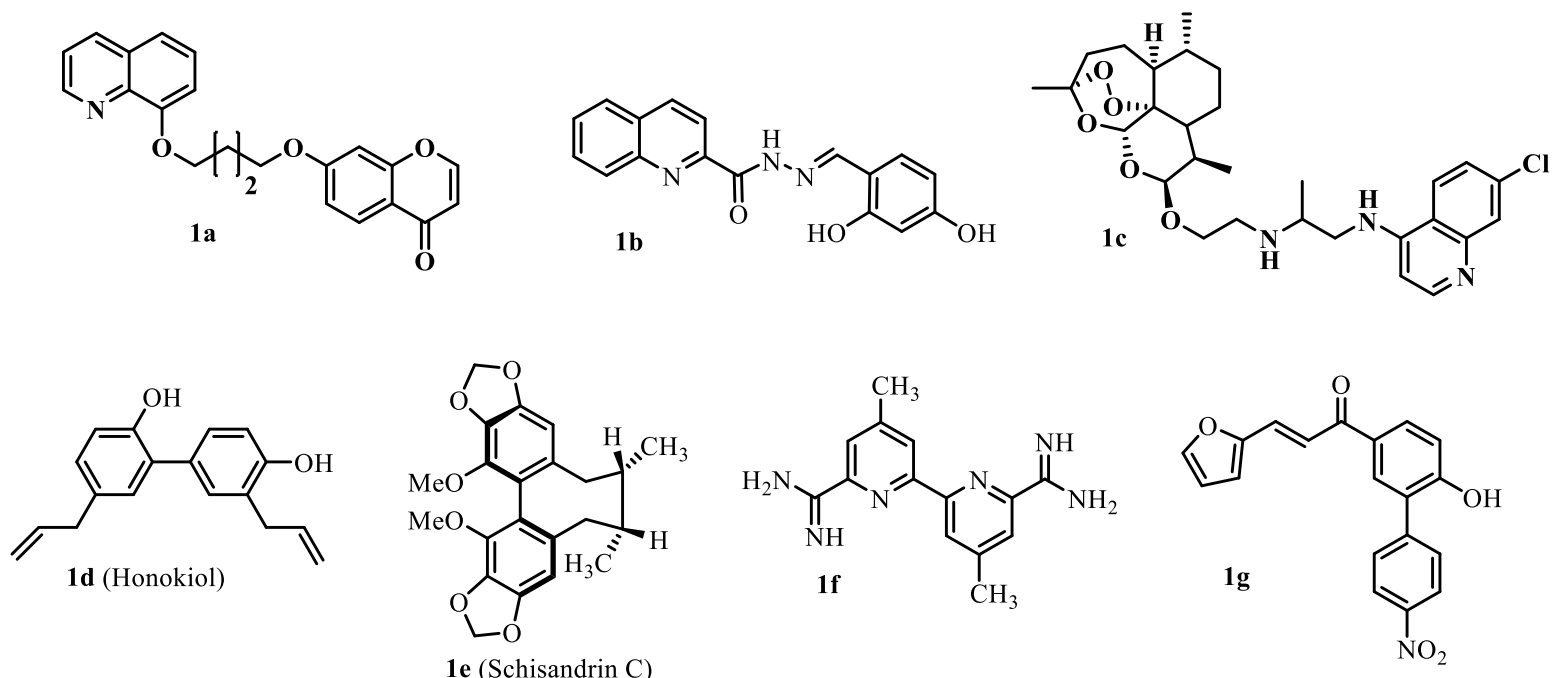

Fig. 1 Biologically actives biphenyl and quinoline hybrids

Hybrid molecules are chemical entities with two (or more than two) structural domains having different biological functions and that can, therefore, to show a dual mode of action acting as two distinct pharmacophores (Cardona-G et al. 2018; Meunier 2008) without necessarily acting on the same biological target (Dunn et al. 2016). A promising strategy based on these class of compounds has recently emerged in medicinal chemistry for the discovery and development of new drugs. In the search for new therapeutic alternatives to treat cutaneous leishmaniasis, Chagas disease and malaria, we designed and synthesized a series of quinoline-biphenyl hybrids, whose general structures are indicated in fig. 2, and their in vitro cytotoxicity, antileishmanial, antitrypanosomal and antiplasmodial activities was in turn evaluated by us. 


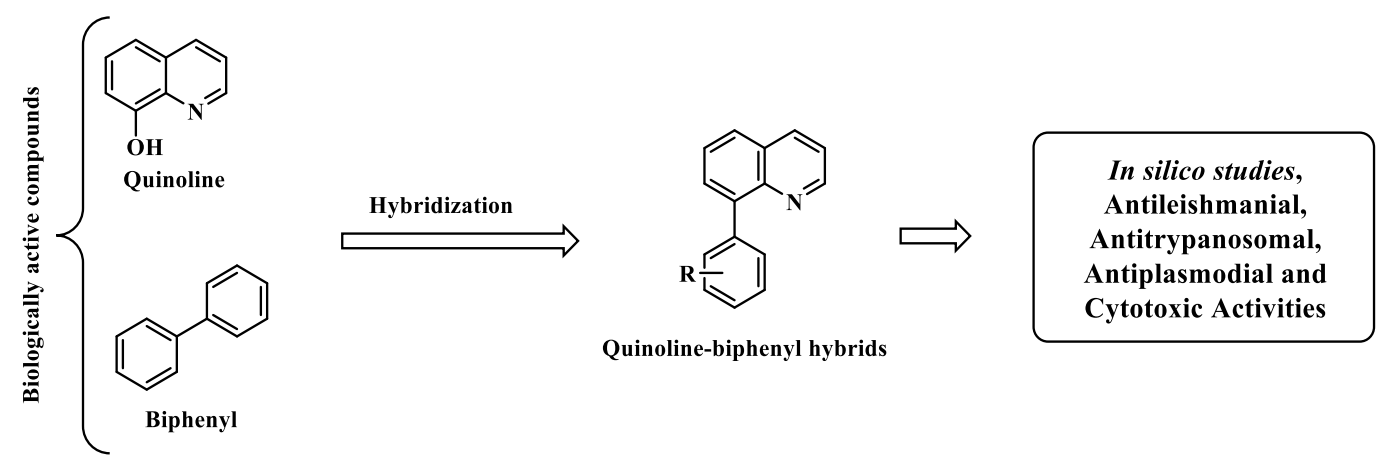

Fig. 2 Design of quinoline-biphenyl hybrids as antiprotozoal agents

\section{Material and methods}

\section{Chemical synthesis}

General remarks

Microwave reactions were carried out in a CEM Discover microwave reactor in sealed vessels (monowave, maximum power $300 \mathrm{~W}$, temperature control by IR sensor, fixed temperature). ${ }^{1} \mathrm{H}$ and ${ }^{13} \mathrm{C}$ NMR spectra were recorded on a Varian instruments operating at 600 (300) MHz. The signals of the deuterated solvent $\left(\mathrm{CDCl}_{3}\right)$ were used as reference $\left(\mathrm{CDCl}_{3}: \delta=7.27 \mathrm{ppm}\right.$ for ${ }^{1} \mathrm{H}$ NMR and $\delta=77.00$ ppm for ${ }^{13} \mathrm{C}$ NMR. Carbon atom types $\left(\mathrm{C}, \mathrm{CH}, \mathrm{CH}_{2}, \mathrm{CH}_{3}\right)$ were determined by using the DEPT (Distortion less Enhancement by Polarization Transfer) or APT (Attached Proton Test) pulse sequence. High resolution mass spectra were recorded using electrospray ionization mass spectrometry (ESI-MS). A QTOF Premier instrument with an orthogonal Z-spray-electrospray interface (Waters, Manchester, UK) was used operating in the W-mode. The drying and cone gas was nitrogen set to flow rates of 300 and $30 \mathrm{~L} / \mathrm{h}$, respectively. Methanol sample solutions (ca. $1 \times 10^{-5} \mathrm{M}$ ) were directly introduced into the ESI spectrometer at a flow rate of $10 \mu \mathrm{L} / \mathrm{min}$. A capillary voltage of $3.5 \mathrm{kV}$ was used in the positive scan mode, and the cone voltage set to $\mathrm{Uc}=10 \mathrm{~V}$. For accurate mass measurements, a $2 \mathrm{mg} / \mathrm{L}$ standard solution of leucine enkephalin was introduced via the lock spray needle at a cone voltage set to $85 \mathrm{~V}$ and a flow rate of $30 \mu \mathrm{L} / \mathrm{min}$. IR spectra were recorded on a Spectrum RX I FT-IR system (PerkinElmer, Waltham, MA, USA) in KBr disks. Silica gel 60 (0.063-0.200 mesh, Merck, Whitehouse Station, NJ, USA) was used for column chromatography, and precoated silica gel plates (Merck 60 F254 $0.2 \mathrm{~mm}$ ) were used for thin layer chromatography (TLC). 


\section{General procedure for the synthesis of aryl-quinolines (4a-4K)}

A mixture of quinolin-8-yl trifluoromethanesulfonate (1 eq), boronic acid $\mathbf{6} \mathbf{a}-\mathbf{k}$ (2 eq), palladium acetate (5\%), triphenylphosphine (10\%), sodium carbonate (7eq) and $4 \mathrm{~mL}$ of n-propanol: distilled $\mathrm{H}_{2} \mathrm{O}$ $(10: 1)$, were heated under ultrasonic radiation for 60 minutes $\left(50^{\circ} \mathrm{C}\right)$. Then the mixture was extracted with ethyl acetate and dried with $\mathrm{Na}_{2} \mathrm{SO}_{4}$ and filtered. The crude reaction mixture was evaporated under reduced pressure and the residue was purified by preparative TLC eluting with a mixture of hexane: ethyl acetate (7:3). The final product was dried to obtain the aryl-quinolines $\mathbf{4} \mathbf{a}-\mathbf{k}$ with yields ranging from $40 \%$ to $52 \%$.

8-phenylquinoline (4a): Yield 62\% (0.47 mmol, $96.8 \mathrm{mg})$; beige oil; IR $(\mathrm{cm}-1)$ : $v_{\max }, 1580(\mathrm{C}=\mathrm{N})$, $1441\left(\mathrm{C}=\mathrm{C}_{\mathrm{Ar}}\right), 800\left(\mathrm{C}-\mathrm{H}_{\mathrm{Ar}}\right) .{ }^{1} \mathrm{H}-\mathrm{NMR}\left(\mathrm{CDCl}_{3}\right): \delta 7.44(1 \mathrm{H}, \mathrm{m}), 7.49(1 \mathrm{H}, \mathrm{d}, J=7.4 \mathrm{~Hz}), 7.58(2 \mathrm{H}, \mathrm{t}, J$ $=15.0 \mathrm{~Hz}), 7.33(2 \mathrm{H}, \mathrm{m}), 7.65(1 \mathrm{H}, \mathrm{t}, J=15.2 \mathrm{~Hz}), 7.78(3 \mathrm{H}, \mathrm{m}), 7.85(1 \mathrm{H}, \mathrm{dd}, J=8.0,1.2 \mathrm{~Hz}), 8.22$ $(1 \mathrm{H}, \mathrm{dd}, J=8.2,1.7 \mathrm{~Hz}), 9.01(1 \mathrm{H}, \mathrm{dd}, J=4.0,1.7 \mathrm{~Hz}) .{ }^{13} \mathrm{C}-\mathrm{NMR}\left(\mathrm{CDCl}_{3}\right): \delta 121.01(\mathrm{CH}), 126.29$ $(\mathrm{CH}), 127.40(\mathrm{CH}), 127.57(\mathrm{CH}), 128.03(2 \mathrm{CH}), 128.74(\mathrm{C}), 130.34(\mathrm{C}), 130.66(2 \mathrm{CH}), 136.28(\mathrm{C})$, 139.59 (C), 140.89 (C), 146.02 (C), 150.27 (CH). ESI-MS: m/z 206.0970 [M + H] ${ }^{+}$, Calc. For $\mathrm{C}_{15} \mathrm{H}_{11} \mathrm{~N}: 206.0969$.

4-(quinolin-8-yl)phenol (4b): Yield 63\% (0.48 mmol, $106.7 \mathrm{mg})$; yellow solid, m.p. 248-250 ${ }^{\circ} \mathrm{C}$; IR $(\mathrm{cm}-1)$ : $v_{\max }, 3058(\mathrm{O}-\mathrm{H}), 1625(\mathrm{C}=\mathrm{N}), 1500\left(\mathrm{C}=\mathrm{C}_{\mathrm{Ar}}\right), 1276(\mathrm{C}-\mathrm{O}-\mathrm{C}), 1230(\mathrm{C}-\mathrm{O}), 809\left(\mathrm{C}-\mathrm{H}_{\mathrm{Ar}}\right) .{ }^{1} \mathrm{H}-$ NMR $\left(\mathrm{CDCl}_{3}\right): \delta 6.89(2 \mathrm{H}, \mathrm{d}, J=7.8 \mathrm{~Hz}), 7.52(2 \mathrm{H}, \mathrm{d}, J=8.0 \mathrm{~Hz}), 7.55(1 \mathrm{H}, \mathrm{m}), 7.65(1 \mathrm{H}, \mathrm{m}), 7.71$ $(1 \mathrm{H}, \mathrm{d}, J=7.0 \mathrm{~Hz}), 7.92(1 \mathrm{H}, \mathrm{d}, J=8.1 \mathrm{~Hz}), 8.40(1 \mathrm{H}, \mathrm{dd}, J=8.3,1.6 \mathrm{~Hz}), 8.90(1 \mathrm{H}, \mathrm{dd}, J=4.1,1.6$ $\mathrm{Hz}), 9.52(1 \mathrm{H}, \mathrm{s}) .{ }^{13} \mathrm{C}-\mathrm{NMR}\left(\mathrm{CDCl}_{3}\right): \delta 115.07(2 \mathrm{CH}), 121.71(\mathrm{CH}), 126.91(\mathrm{CH}), 127.50(\mathrm{CH}), 128.90$ (C), $129.97(\mathrm{CH}), 130.28(\mathrm{C}), 132.22(2 \mathrm{CH}), 136.86(\mathrm{CH}), 140.32(\mathrm{C}), 145.75(\mathrm{C}), 150.39(\mathrm{CH})$, 157.22 (C). ESI-MS: m/z 222.0919 [M + H $]^{+}$, Calc. For $\mathrm{C}_{15} \mathrm{H}_{11} \mathrm{NO}: 222.0916$.

8- (4-methoxyphenyl) quinoline (4c): Yield 61\% (0.46 mmol, $109.2 \mathrm{mg})$; yellow solid, m.p. 198-200 ${ }^{\circ} \mathrm{C}$; IR $(\mathrm{cm}-1): v_{\max }, 1596(\mathrm{C}=\mathrm{N}), 1441(\mathrm{C}=\mathrm{CAr}), 817(\mathrm{C}-\mathrm{HAr}) .{ }^{1} \mathrm{H}-\mathrm{NMR}(\mathrm{CDCl} 3): \delta 3.83(3 \mathrm{H}, \mathrm{s})$, $7.05(2 \mathrm{H}, \mathrm{d}, J=8.5 \mathrm{~Hz}), 7.56(1 \mathrm{H}, \mathrm{m}), 7.62(2 \mathrm{H}, \mathrm{d}, J=8.5 \mathrm{~Hz}), 7.66(1 \mathrm{H}, \mathrm{t}, J=15.3 \mathrm{~Hz}), 7.74(1 \mathrm{H}, \mathrm{d}$, $J=7.0 \mathrm{~Hz}), 7.96(1 \mathrm{H}, \mathrm{d}, \mathrm{J}=8.1 \mathrm{~Hz}), 8.42(1 \mathrm{H}, \mathrm{d}, \mathrm{J}=8.2 \mathrm{~Hz}), 8.90(1 \mathrm{H}, \mathrm{dd}, \mathrm{J}=4.1,1.6 \mathrm{~Hz}) .{ }^{13} \mathrm{C}-\mathrm{NMR}$ $\left(\mathrm{CDCl}_{3}\right): \delta 55.16\left(\mathrm{OCH}_{3}\right), 113.25(2 \mathrm{CH}), 121.35(\mathrm{CH}), 126.48(\mathrm{CH}), 127.38(\mathrm{C}), 128.45(\mathrm{C}), 129.70$ $(\mathrm{CH}), 131.44(\mathrm{CH}), 131.77(2 \mathrm{CH}), 136.47(\mathrm{CH}), 139.49(\mathrm{C}), 145.25(\mathrm{C}), 150.08(\mathrm{CH}), 158.59(\mathrm{C})$. ESI-MS: m/z 236.1075 [M + H]+, Calc. For $\mathrm{C}_{16} \mathrm{H}_{13} \mathrm{NO}: 236.1072$.

2-(quinolin-8-yl)phenol (4d): Yield 62\% (0.47 mmol, $105.0 \mathrm{mg})$; yellow solid, m.p. 250-252 ${ }^{\circ} \mathrm{C}$; IR $(\mathrm{cm}-1)$ : $v_{\max }, 3028(\mathrm{O}-\mathrm{H}), 1610(\mathrm{C}=\mathrm{N}), 1438\left(\mathrm{C}=\mathrm{C}_{\mathrm{Ar}}\right), 1267(\mathrm{C}-\mathrm{O}-\mathrm{C}), 1228(\mathrm{C}-\mathrm{O}), 810\left(\mathrm{C}-\mathrm{H}_{\mathrm{Ar}}\right) .{ }^{1} \mathrm{H}-$ NMR $\left(\mathrm{CDCl}_{3}\right): \delta 7.08(1 \mathrm{H}, \mathrm{t}, \mathrm{J}=15.0 \mathrm{~Hz}), 7.19(1 \mathrm{H}, \mathrm{d}, J=8.1 \mathrm{~Hz}), 7.40(2 \mathrm{H}, \mathrm{t}, J=15.0 \mathrm{~Hz}), 7.43(1 \mathrm{H}$, $\mathrm{d}, J=7.7 \mathrm{~Hz}), 7.53(1 \mathrm{H}, \mathrm{m}), 7.71(1 \mathrm{H}, \mathrm{t}, J=15.3 \mathrm{~Hz}), 7.90(2 \mathrm{H}, \mathrm{t}, J=14.4 \mathrm{~Hz}), 8.35(1 \mathrm{H}, \mathrm{dd}, J=8.3$, $1.4 \mathrm{~Hz}), 8.93(1 \mathrm{H}, \mathrm{dd}, \mathrm{J}=4.1,1.6 \mathrm{~Hz}), 10.77(1 \mathrm{H}, \mathrm{s}) .{ }^{13} \mathrm{C}-\mathrm{NMR}\left(\mathrm{CDCl}_{3}\right): \delta 119.62(\mathrm{CH}), 120.93(\mathrm{CH})$, $121.12(\mathrm{CH}), 127.58(\mathrm{CH}), 127.80(\mathrm{CH}), 128.25(\mathrm{C}), 128.65(\mathrm{C}), 129.93(\mathrm{CH}), 132.62(\mathrm{CH}), 133.39$ $(\mathrm{CH}), 138.56(\mathrm{CH}), 138.95(\mathrm{C}), 145.31(\mathrm{C}), 149.25(\mathrm{CH}), 155.08(\mathrm{C}) . \mathrm{ESI}-\mathrm{MS}: \mathrm{m} / \mathrm{z} 222.0919$ [M + $\mathrm{H}]^{+}$, Calc. For $\mathrm{C}_{15} \mathrm{H}_{11} \mathrm{NO}: 222.0920$. 
8-(4-fluorophenyl) quinoline (4e): Yield 59\% (0.47 mmol, $96.8 \mathrm{mg})$; white solid, m.p. 164-166 ${ }^{\circ} \mathrm{C}$; IR $(\mathrm{cm}-1): v_{\max }, 1600(\mathrm{C}=\mathrm{N}), 1400\left(\mathrm{C}=\mathrm{C}_{\mathrm{Ar}}\right), 820\left(\mathrm{C}-\mathrm{H}_{\mathrm{Ar}}\right) .{ }^{1} \mathrm{H}-\mathrm{NMR}\left(\mathrm{CDCl}_{3}\right): \delta 7.29(2 \mathrm{H}, \mathrm{t}, J=17.0 \mathrm{~Hz})$, $7.46(1 \mathrm{H}, \mathrm{m}), 7.66(1 \mathrm{H}, \mathrm{t}, J=15.1 \mathrm{~Hz}), 7.77(3 \mathrm{H}, \mathrm{m}), 7.87(1 \mathrm{H}, \mathrm{d}, J=8.0 \mathrm{~Hz}), 8.24(1 \mathrm{H}, \mathrm{d}, J=8.2 \mathrm{~Hz})$, $9.02(1 \mathrm{H}, \mathrm{dd}, J=4.0,1.4 \mathrm{~Hz}) .{ }^{13} \mathrm{C}-\mathrm{NMR}\left(\mathrm{CDCl}_{3}\right): \delta 114.76(\mathrm{CH}), 115.04(\mathrm{CH}), 121.05(\mathrm{CH}), 126.25$ $(\mathrm{CH}), 127.67(\mathrm{CH}), 128.73(\mathrm{C}), 130.17(\mathrm{CH}), 132.16(\mathrm{CH}), 132.26(\mathrm{CH}), 135.40(\mathrm{C}), 135.44(\mathrm{C})$, $136.29(\mathrm{CH}), 139.68(\mathrm{C}), 145.87(\mathrm{C}), 150.24(\mathrm{CH})$. ESI-MS: m/z $224.0876[\mathrm{M}+\mathrm{H}]^{+}$, Calc. For $\mathrm{C}_{15} \mathrm{H}_{10} \mathrm{FN}: 224.0875$.

8-(4-nitrophenyl) quinoline (4f): Yield 54\% (0.41 mmol, $102.8 \mathrm{mg})$; yellow solid, m.p. $173-175{ }^{\circ} \mathrm{C}$; IR $\left(\mathrm{cm}^{-1}\right): v_{\max }, 1595(\mathrm{C}=\mathrm{N}), 1510(\mathrm{~N}-\mathrm{O}), 1496\left(\mathrm{C}=\mathrm{C}_{\mathrm{Ar}}\right), 817\left(\mathrm{C}-\mathrm{H}_{\mathrm{Ar}}\right) .{ }^{1} \mathrm{H}-\mathrm{NMR}\left(\mathrm{CDCl}_{3}\right): \delta 7.54(1 \mathrm{H}, \mathrm{m})$, $7.72(2 \mathrm{H}, \mathrm{t}, J=15.3 \mathrm{~Hz}), 7.82(1 \mathrm{H}, \mathrm{dd}, J=7.1,1.4 \mathrm{~Hz}), 7.94(2 \mathrm{H}, \mathrm{d}, J=8.8 \mathrm{~Hz}), 7.98(1 \mathrm{H}, \mathrm{dd}, J=8.2$, $1.3 \mathrm{~Hz}), 8.32(1 \mathrm{H}, \mathrm{dd}, J=8.3,1.7 \mathrm{~Hz}), 8.40(2 \mathrm{H}, \mathrm{d}, J=8.7 \mathrm{~Hz}), 9.00(1 \mathrm{H}, \mathrm{dd}, J=4.1,1.7 \mathrm{~Hz}) .{ }^{13} \mathrm{C}-$ NMR $\left(\mathrm{CDCl}_{3}\right): \delta 121.55(\mathrm{CH}), 123.22(2 \mathrm{CH}), 126.34(\mathrm{CH}), 128.80(\mathrm{C}), 129.06(\mathrm{CH}), 130.47(\mathrm{CH})$, $131.56(2 \mathrm{CH}), 136.53(\mathrm{CH}), 138.49(\mathrm{C}), 145.59(\mathrm{C}), 146.44(\mathrm{C}), 147.07(\mathrm{C}), 150.69(\mathrm{CH})$. ESI-MS: $\mathrm{m} / \mathrm{z} 251.0821[\mathrm{M}+\mathrm{H}]^{+}$, Calc. For $\mathrm{C}_{16} \mathrm{H}_{13} \mathrm{NO}: 251.0820$.

8-(2,3-dimethoxyphenyl) quinoline (4g): Yield 55\% (0.42 mmol, $111.4 \mathrm{mg})$; beig palid solid, m.p. 244$246{ }^{\circ} \mathrm{C}$; IR $\left(\mathrm{cm}^{-1}\right): v_{\max } 1583(\mathrm{C}=\mathrm{N}), 1440(\mathrm{C}=\mathrm{C}$ Ar $), 1233(\mathrm{C}-\mathrm{O}-\mathrm{C}), 800\left(\mathrm{C}-\mathrm{H}_{\mathrm{Ar}}\right) .{ }^{1} \mathrm{H}-\mathrm{NMR}\left(\mathrm{CDCl}_{3}\right): \delta$ $3.44(3 \mathrm{H}, \mathrm{s}), 3.91(3 \mathrm{H}, \mathrm{s}), 6.88(1 \mathrm{H}, \mathrm{dd}, \mathrm{J}=7.4,1.6 \mathrm{~Hz}), 7.11(1 \mathrm{H}, \mathrm{dd}, J=8.2,1.6 \mathrm{~Hz}), 7.16(1 \mathrm{H}, \mathrm{d}, J=$ $8.2 \mathrm{~Hz}), 7.50(1 \mathrm{H}, \mathrm{m}), 7.63(2 \mathrm{H}, \mathrm{d}, J=5.08 \mathrm{~Hz}), 7.95(1 \mathrm{H}, \mathrm{t}, J=9,7 \mathrm{~Hz}), 8.37(1 \mathrm{H}, \mathrm{dd}, J=8.2,1,6$ $\mathrm{Hz}), 8.74(1 \mathrm{H}, \mathrm{dd}, \mathrm{J}=4.2,1.7 \mathrm{~Hz}) .{ }^{13} \mathrm{C}-\mathrm{NMR}\left(\mathrm{CDCl}_{3}\right): \delta 54.44\left(\mathrm{OCH}_{3}\right), 54.49\left(\mathrm{OCH}_{3}\right), 98.39(\mathrm{CH})$, $104.32(\mathrm{CH}), 120.68(\mathrm{CH}), 121.28(\mathrm{C}), 126.08(\mathrm{CH}), 127.13(\mathrm{CH}), 128.65(\mathrm{C}), 131.35(\mathrm{CH}), 131.63$ $(\mathrm{CH}), 136.96(\mathrm{CH}), 137.98(\mathrm{C}), 146.24(\mathrm{C}), 149.12(\mathrm{CH}), 158.38(\mathrm{C}), 161.01(\mathrm{C}) . \mathrm{ESI}-\mathrm{MS}: \mathrm{m} / \mathrm{z}$ $266.1181[\mathrm{M}+\mathrm{H}]^{+}$, Calc. For $\mathrm{C}_{17} \mathrm{H}_{15} \mathrm{NO}_{2}: 266.1183$.

8-(2,4-dimethoxyphenyl) quinoline (4h): Yield 60\% (0.46 mmol, $121.1 \mathrm{mg})$; beig palid solid, m.p. 240$242{ }^{\circ} \mathrm{C}$; IR $\left(\mathrm{cm}^{-1}\right): v_{\max } 1593(\mathrm{C}=\mathrm{N}), 1492(\mathrm{C}=\mathrm{C}$ Ar $), 1215(\mathrm{C}-\mathrm{O}-\mathrm{C}), 817\left(\mathrm{C}-\mathrm{H}_{\mathrm{Ar}}\right) .{ }^{1} \mathrm{H}-\mathrm{NMR}\left(\mathrm{CDCl}_{3}\right): \delta$ $3.62(3 \mathrm{H}, \mathrm{s}), 3.86(3 \mathrm{H}, \mathrm{s}), 6.63(1 \mathrm{H}, \mathrm{dd}, J=8.1,2.2 \mathrm{~Hz}), 6.66(1 \mathrm{H}, \mathrm{d}, J=2.2 \mathrm{~Hz}), 7.16(1 \mathrm{H}, \mathrm{d}, J=8.2$ $\mathrm{Hz}), 7.47(1 \mathrm{H}, \mathrm{m}), 7.59(2 \mathrm{H}, \mathrm{t}, J=6.5 \mathrm{~Hz}), 7.88(1 \mathrm{H}, \mathrm{m}), 8.33(1 \mathrm{H}, \mathrm{dd}, J=8.4,1,4 \mathrm{~Hz}), 8.70(1 \mathrm{H}, \mathrm{dd}, J$ $=4.1,1.6 \mathrm{~Hz}) .{ }^{13} \mathrm{C}-\mathrm{NMR}\left(\mathrm{CDCl}_{3}\right): \delta 54.44\left(\mathrm{OCH}_{3}\right), 54.49\left(\mathrm{OCH}_{3}\right), 98.39(\mathrm{CH}), 104.32(\mathrm{CH}), 120.68$ $(\mathrm{CH}), 121.28(\mathrm{C}), 126.08(\mathrm{CH}), 127.13(\mathrm{CH}), 128.65(\mathrm{C}), 131.35(\mathrm{CH}), 131.63(\mathrm{CH}), 136.96(\mathrm{CH})$, 137.98 (C), $146.24(\mathrm{C}), 149.12(\mathrm{CH}), 158.38$ (C), 161.01 (C). ESI-MS: m/z 266.1181 [M + H] $]^{+}$Calc. For $\mathrm{C}_{17} \mathrm{H}_{15} \mathrm{NO}_{2}: 266.1182$.

8-(2,5-dimethoxyphenyl) quinoline (4i): Yield 53\% (0.41 mmol, $108.7 \mathrm{mg})$; beig palid solid, m.p. 246$248{ }^{\circ} \mathrm{C}$; IR $\left(\mathrm{cm}^{-1}\right): v_{\max } 1599(\mathrm{C}=\mathrm{N}), 1441(\mathrm{C}=\mathrm{C}$ Ar $), 1283(\mathrm{C}-\mathrm{O}-\mathrm{C}), 813\left(\mathrm{C}-\mathrm{H}_{\mathrm{Ar}}\right) .{ }^{1} \mathrm{H}-\mathrm{NMR}\left(\mathrm{CDCl}_{3}\right): \delta$ $3.57(3 \mathrm{H}, \mathrm{s}), 3.76(3 \mathrm{H}, \mathrm{s}), 6.84(1 \mathrm{H}, \mathrm{d}, J=3.1 \mathrm{~Hz}), 6,97(1 \mathrm{H}, \mathrm{dd}, J=9.0,2.9 \mathrm{~Hz}), 7.02(1 \mathrm{H}, \mathrm{d}, J=8.7$ $\mathrm{Hz}), 7.48(1 \mathrm{H}, \mathrm{m}), 7.60(2 \mathrm{H}, \mathrm{d}, J=4.90 \mathrm{~Hz}), 7.91(1 \mathrm{H}, \mathrm{t}, J=9,7 \mathrm{~Hz}), 8.34(1 \mathrm{H}, \mathrm{dd}, J=8.2,1,6 \mathrm{~Hz})$, $8.72(1 \mathrm{H}, \mathrm{dd}, J=4.2,1.7 \mathrm{~Hz}) .{ }^{13} \mathrm{C}-\mathrm{NMR}\left(\mathrm{CDCl}_{3}\right): \delta 55.72\left(\mathrm{OCH}_{3}\right), 56.14\left(\mathrm{OCH}_{3}\right), 113.20(\mathrm{CH})$, $114.20(\mathrm{CH}), 118.28(\mathrm{CH}), 121.74(\mathrm{CH}), 126.98(\mathrm{CH}), 128.43(\mathrm{CH}), 129.56(\mathrm{C}), 130.63(\mathrm{C}), 131.99$ $(\mathrm{CH}), 137.88(\mathrm{CH}), 138.79(\mathrm{C}), 146.89(\mathrm{C}), 150.29(\mathrm{CH}), 152.63(\mathrm{C}), 154.48(\mathrm{C}) . \mathrm{ESI}-\mathrm{MS}: \mathrm{m} / \mathrm{z}$ $266.1181[\mathrm{M}+\mathrm{H}]^{+}$, Calc. For $\mathrm{C}_{17} \mathrm{H}_{15} \mathrm{NO}_{2}: 266.1183$.

8-(2,6-dimethoxyphenyl) quinoline (4j): Yield 50\% (0.38 mmol, $100.8 \mathrm{mg})$; white solid, m.p. 238-240 ${ }^{\circ} \mathrm{C}$; IR $\left(\mathrm{cm}^{-1}\right): v_{\max } 1600(\mathrm{C}=\mathrm{N}), 1441\left(\mathrm{C}=\mathrm{C}_{\mathrm{Ar}}\right), 1240(\mathrm{C}-\mathrm{O} \mathrm{C}), 798\left(\mathrm{C}-\mathrm{H}_{\mathrm{Ar}}\right) .{ }^{1} \mathrm{H}-\mathrm{NMR}\left(\mathrm{CDCl}_{3}\right): \delta 3.66$ $(6 \mathrm{H}, \mathrm{s}), 6.76(2 \mathrm{H}, \mathrm{d}, J=8.3 \mathrm{~Hz}), 7.39(2 \mathrm{H}, \mathrm{m}), 7.63(2 \mathrm{H}, \mathrm{t}, J=7.08 \mathrm{~Hz}), 7.85(1 \mathrm{H}, \mathrm{dd}, J=6.8,2.9 \mathrm{~Hz})$, $8.19(1 \mathrm{H}, \mathrm{dd}, J=8.2,1.7 \mathrm{~Hz}), 8.88(1 \mathrm{H}, \mathrm{dd}, J=4.2,1.8 \mathrm{~Hz}) \cdot{ }^{13} \mathrm{C}-\mathrm{NMR}\left(\mathrm{CDCl}_{3}\right): \delta 55.73\left(2 \mathrm{OCH}_{3}\right)$, 
$104.17(2 \mathrm{CH}), 120.38(\mathrm{CH}), 123.12(\mathrm{C}), 125.79(\mathrm{CH}), 127.14(\mathrm{CH}), 128.11(\mathrm{C}), 128.87(\mathrm{CH}), 131.31$ $(\mathrm{CH}), 134.18(\mathrm{C}), 135.85(\mathrm{CH}), 146.81(\mathrm{C}), 149.66(\mathrm{CH}), 157.94(2 \mathrm{C}) . \mathrm{ESI}-\mathrm{MS}: \mathrm{m} / \mathrm{z} 266.1181$ [M + $\mathrm{H}]^{+}$, Calc. For $\mathrm{C}_{17} \mathrm{H}_{15} \mathrm{NO}_{2}: 266.1178$.

8-(3,4-dimethoxyphenyl) quinoline (4k): Yield 65\% (0.50 mmol, $132.6 \mathrm{mg})$; white solid, m.p. 243-245 ${ }^{\circ} \mathrm{C}$; IR $\left(\mathrm{cm}^{-1}\right): v_{\max } 1568(\mathrm{C}=\mathrm{N}), 1441\left(\mathrm{C}=\mathrm{C}_{\mathrm{Ar}}\right), 1276(\mathrm{C}-\mathrm{O} \mathrm{C}), 815\left(\mathrm{C}-\mathrm{H}_{\mathrm{Ar}}\right) .{ }^{1} \mathrm{H}-\mathrm{NMR}\left(\mathrm{CDCl}_{3}\right): \delta 3.94$ $(3 \mathrm{H}, \mathrm{s}), 3.96(3 \mathrm{H}, \mathrm{s}), 7.04(1 \mathrm{H}, \mathrm{d}, J=8.1), 7.33(2 \mathrm{H}, \mathrm{m}), 7.41(1 \mathrm{H}, \mathrm{m}), 7.60(1 \mathrm{H}, \mathrm{t}, J=15.1 \mathrm{~Hz}), 7.80$ $(2 \mathrm{H}, \mathrm{m}), 8.18(1 \mathrm{H}, \mathrm{dd}, J=8.4,1.6 \mathrm{~Hz}), 8.99(1 \mathrm{H}, \mathrm{dd}, J=4.1,1.6 \mathrm{~Hz}) \cdot{ }^{13} \mathrm{C}-\mathrm{NMR}\left(\mathrm{CDCl}_{3}\right): \delta 55.68$ $\left(\mathrm{OCH}_{3}\right), 55.69\left(\mathrm{OCH}_{3}\right), 110.73(\mathrm{CH}), 113.95(\mathrm{CH}), 120.74(\mathrm{CH}), 122.78(\mathrm{CH}), 126.05(\mathrm{CH}), 127.04$ $(\mathrm{CH}), 128.55(\mathrm{C}), 129.85(\mathrm{CH}), 132.03(\mathrm{C}), 136.08(\mathrm{CH}), 140.33(\mathrm{C}), 145.83(\mathrm{C}), 148.14(\mathrm{C}), 148.31$ (C), $149.94(\mathrm{CH})$. ESI-MS: m/z 266.1181 [M + H] $]^{+}$, Calc. For $\mathrm{C}_{17} \mathrm{H}_{15} \mathrm{NO}_{2}: 266.1180$.

\section{Biological activity assays}

In vitro Cytotoxicity

The cytotoxic activity of the compounds was assessed in the human promonocytic cell line U-937 (ATCC CRL-1593.2 $2^{\mathrm{TM}}$ ) based on the viability evaluated by the MTT (3-(4,5-dimethylthiazol-2-yl)-2,5diphenyltetrazolium bromide) assay as described elsewhere (Taylor et al. 2011). Briefly, U-937 cells grown in tissue flasks were harvested and washed with phosphate buffered saline (PBS) by centrifugation. Cells were counted and adjusted at $1 \times 10^{6}$ cells/mL of complete culture medium (RPMI1640 supplemented with $10 \%$ Fetal Bovine Serum-FBS and 1\% of antibiotics $-100 \mathrm{U} / \mathrm{mL}$ penicillin and $0.1 \mathrm{mg} / \mathrm{mL}$ streptomycin. One hundred $\mu \mathrm{L}$ of cell suspension were dispensed into each well of a 96well cell-culture plate and then $100 \mu \mathrm{L}$ of two-fold serial dilutions of the compounds (starting at 200 $\mu \mathrm{g} / \mathrm{mL})$ in complete RPMI 1640 medium were added. Plates were incubated at $37{ }^{\circ} \mathrm{C}, 5 \% \mathrm{CO}_{2}$ during $72 \mathrm{~h}$ in the presence of compounds. Then, $10 \mu \mathrm{L} /$ well of MTT solution $(0.5 \mathrm{mg} / \mathrm{mL})$ was added into each well and plate was incubated at $37^{\circ} \mathrm{C}$ for $3 \mathrm{~h}$. The formazan crystals were dissolved by adding 100 $\mu \mathrm{L} /$ well of dimethyl sulfoxide and 30 min incubation. Cell viability was determined according to the intensity of color (absorbance) registered as optical densities (O.D) obtained at $570 \mathrm{~nm}$ in a spectrophotometer (Varioskan ${ }^{\mathrm{TM}}$ Flash Multimode Reader - Thermo Scientific, USA). Cells cultured in absence of compounds were used as control of viability (negative control), while doxorrubicin was used as control for cytotoxic drugs. Non-specific absorbance was corrected by subtracting the O.D of the blank. Assays were conducted in two independent runs with three replicates per each concentration tested. 


\section{In vitro antileishmanial activity}

The activity of compounds was evaluated on intracellular amastigotes of $L$. $(V)$ panamensis transfected with the green fluorescent protein gene (MHOM/CO/87/UA140-EGFP) (Pulido et al., 2012). The effect of each compound was determined according to the inhibition of the infection evidenced by both decrease of the infected cells and decrease of intracellular parasite amount. Briefly, U-937 human cells at a concentration of $3 \times 10^{5}$ cells $/ \mathrm{mL}$ in RPMI 1640 containing $0.1 \mu \mathrm{g} / \mathrm{mL}$ of phorbol-12-myristate-13-acetate (PMA) were dispensed into each well of a 24-well cell culture plate and then infected with 5 days-old promastigotes in a 15:1 parasites per cell ratio. Plates were incubated at $34{ }^{\circ} \mathrm{C}, 5 \% \mathrm{CO}_{2}$ during $3 \mathrm{~h}$ and cells were washed two times with PBS to eliminate not internalized parasites. One mL of fresh complete RPMI 1640 medium supplemented with 10\% FBS and 1\%

antibiotics was added into each well, cells were incubated again to guarantee multiplication of intracellular parasites. After $24 \mathrm{~h}$ of infection, culture medium was replaced by fresh culture medium containing each compound at 50-6.12 and $1.56 \mu \mathrm{g} / \mathrm{mL}$ and plates were incubated at $37{ }^{\circ} \mathrm{C}, 5 \% \mathrm{CO}_{2}$. After $72 \mathrm{~h}$, inhibition of the infection was determined. For this, cells were removed from the bottom plate with a trypsin/EDTA $(250 \mathrm{mg})$ solution; recovered cells were centrifuged at $1100 \mathrm{rpm}$ during 10 min at $4{ }^{\circ} \mathrm{C}$, the supernatant was discarded and cells were washed with $1 \mathrm{~mL}$ of cold PBS and centrifuged at $1100 \mathrm{rpm}$ during $10 \mathrm{~min}$ at $4{ }^{\circ} \mathrm{C}$. The supernatant was discarded and cells were suspended in $500 \mu \mathrm{L}$ of PBS and analyzed by flow cytometry (FC 500MPL, Cytomics, Brea, CA, US). All determinations for each compound including and standard drugs were carried out in triplicate, in two independent experiments (Buckner et al., 1996; Pulido et al., 2012). Activity of tested compounds was carried out in parallel with infection progress in culture medium alone and in culture medium with amphotericin B and meglumine antimoniate as antileishmanial drugs (positive controls).

In vitro antitrypanosomal Activity

T. cruzi, Tulahuen strain transfected with $\beta$-galactosidase gene (donated by Dr. F. S. Buckner, University of Washington) were maintained in vitro as epimastigotes by culturing in modified NovyMCNeal-Nicolle (NNN) medium. The U-937 cells were adjusted at $2.5 \times 10^{6}$ cells $/ \mathrm{mL}$ of complete RPMI-1640 medium containing $0.1 \mu \mathrm{g} / \mathrm{mL}$ of phorbol myristate acetate to induce differentiation to macrophages. Then, $100 \mu \mathrm{L}$ of this cell suspension were dispensed into each well of a 96-well cellculture plate. After $24 \mathrm{~h}$ of incubation at $37{ }^{\circ} \mathrm{C}, 5 \% \mathrm{CO}_{2}$, macrophages were infected with early stationary growth phase (10 days in culture) epimastigotes, at the concentration of $12.5 \times 10^{5}$ parasites/mL of complete RPMI 1640 medium equivalent to 5:1 (parasites per cell) ratio. Plates were 
incubated at $34{ }^{\circ} \mathrm{C}, 5 \% \mathrm{CO}_{2}$ during 24 hours to allow the conversion to intracellular amastigotes. Extracellular parasites were removed by washing twice with $100 \mu \mathrm{L}$ of PBS. Then, $100 \mu \mathrm{L}$ of each concentration $(100-25-6.12$ and $1.56 \mu \mathrm{g} / \mathrm{mL})$ of compounds were added to infected cells, plates were incubated at $34{ }^{\circ} \mathrm{C}, 5 \% \mathrm{CO}_{2}$. After $72 \mathrm{~h}$ of incubation plate wells were washed twice with PBS and the $\beta$-galactosidase activity was measured by spectrophotometry adding $100 \mu \mathrm{M}$ of the chromogenic substrate CPRG (chlorophenol red-beta-D-galactopyranoside) and 0.1\% nonidet P-40 to each well. After $3 \mathrm{~h}$ of incubation at $25{ }^{\circ} \mathrm{C}$, absorbance was read at $570 \mathrm{~nm}$ in a spectrophotometer (Varioskan $^{\mathrm{TM}}$ Flash Multimode Reader - Thermo Scientific, USA). Infected cells exposed to benznidazole were used as control for antitrypanosomal activity (positive control) while infected cells incubated in complete RPMI 1640 culture medium were used as control for infection (negative control). Non-specific absorbance was corrected by subtracting the O.D of the blank. Determinations were done by triplicate in at least two independent experiments (Insuasty et al. 2015).

\section{In vitro Antiplasmodial Activity}

The antiplasmodial activity was evaluated in asynchronic cultures of $P$. falciparum (NF54 strain), maintained in standard culture conditions. The effect of each compound over the growth of the parasites was determined by Plasmodium lactate dehydrogenase assay (pLDH) (Nkhoma et al. 2007; Londoño et al., 2016). Parasites were plated in the trophozoite phase at $1 \%$ hematocrit and 0.5 $\%$ parasitemia in $100 \mu \mathrm{L}$ of each compound at an defined concentration $(1000-25-6.25-1.56$ $\mathrm{ug} / \mathrm{mL}$ ). Plates were incubated in an atmosphere with a gas mixture of $4 \% \mathrm{O}_{2}, 3 \% \mathrm{CO}_{2}$, and $97 \% \mathrm{~N}_{2}$, and incubated at $37^{\circ} \mathrm{C}$ for 72 hours. Meanwhile, two reagents for detecting and measuring the LDH enzyme were prepared. The first of these was the Malstat reagent ( $400 \mu \mathrm{L}$ of Triton X-100 in 80 $\mathrm{mL}$ of deionized water, $4.0 \mathrm{~g}$ L-lactate , $1.32 \mathrm{~g}$ Tris buffer and $0.022 \mathrm{~g}$ of 3 -acetylpyridine adenine dinucleotide (APAD), adjusting the $\mathrm{pH}$ to 9 with hydrochloric acid, and a volume of $200 \mathrm{~mL}$ with deionized water. The second reagent is NBT/PES solution (1-6 g nitro blue tetrazolium salt and 0.008 g phenazine ethosulfate in $100 \mathrm{~mL}$ of deionized water. The solution was stored in a foil-covered container and kept at $4^{\circ} \mathrm{C}$ until required. When incubation was complete, plates were harvested and subjected to three 20 -minute freeze-thaw cycles to resuspend the culture. Thereafter, $100 \mu \mathrm{L}$ of Malstat reagent and $25 \mu \mathrm{L}$ of NBT/PES solution were added to each well of a new, duplicate flat-bottomed 96-well microtiter plate. The culture in each of the wells of the original plate was resuspended by mixing with a multichannel pipette. Thereafter, $15 \mu \mathrm{L}$ of the culture was taken from each well and added to the corresponding well of the Malstat plate, thereby initiating the LDH 
reaction. Color development of the $\mathrm{LDH}$ plate was monitored colorimetrically at $650 \mathrm{~nm}$ in the Varioskan Flahs readet after an hour of incubation in the dark.

Data Analysis

Cytotoxicity was determined according to cell growth (viability) and mortality percentages obtained for each isolated experiment (compounds, doxorubicin and culture medium). Results were expressed as 50 lethal concentrations $\left(\mathrm{LC}_{50}\right)$, corresponding to the concentration necessary to eliminate $50 \%$ of cells, calculated by Probit analysis (Finney, 1978). Percentage of viability was calculated by Equation 1, where the optical density (O.D) of control corresponds to $100 \%$ of viability (cell growth).

$\%$ Mortality $=1-[($ O.D Exposed cells $) /($ O.D Control cells $) \times 100]$

Antileishmanial activity was determined according to percentage of infected cells and parasite amount obtained for each experimental condition by flow cytometer. The percentage of infected cells was determined as the number of positive events by green fluorescence (parasites) and forward side sctter dotplot analysis. On the other hand, the parasitic amount was determined by analysis of mean fluorescence intensity (MFI) (Pulido et al., 2012).

The parasitemia inhibition was calculated by equation 2, where the MFI of control corresponds to $100 \%$ of parasitemia. In turn, inhibition percentage corresponds to 100 - \% Parasitemia. Results of antileishmanial activity was expressed as $50 \%$ effective concentrations $\left(\mathrm{EC}_{50}\right)$ determined by the Probit method (Finney, 1978):

$\%$ inhibition $=1-[($ MFI Exposed parasites $) /($ MFI Control parasites $) \times 100]$

Similarly, antitrypanosomal activity was determined according to the percentage of infected cells and parasite amount obtained for each experimental condition by colorimetry. The parasite inhibition was calculated by equation 3, where the O.D of control corresponds to $100 \%$ of parasites. Results of antitrypanosomal activity were also expressed as $\mathrm{EC}_{50}$ determined by the Probit method (Finney, 1978):

$\%$ inhibition $=1-[($ O.D Exposed parasites $) /($ O.D Control parasites $) \times 100]$

The antiplasmodial activity of each compound was evidenced by the reduction of the O.D. The inhibition of parasitemia percentage was calculated by equation 3 . 
The cytotoxicity was graded according to the $\mathrm{LC}_{50}$ value as high cytotoxicity: $\mathrm{LC}_{50}<100 \mu \mathrm{g} / \mathrm{mL}$, moderate cytotoxicity: $\mathrm{LC}_{50}>100$ to $<200 \mu \mathrm{g} / \mathrm{mL}$, and potentially non-cytotoxicity: $\mathrm{LC}_{50}>200$ $\mu \mathrm{g} / \mathrm{mL}$.

Antiprotozoal activity (antileishmanial, antitrypanosomal or antiplasmodial) was graded according to the $\mathrm{EC}_{50}$ or $\mathrm{IC}_{50}$ values as high activity: $\mathrm{EC}_{50}<20 \mu \mathrm{g} / \mathrm{mL}$, moderate activity: $\mathrm{EC}_{50}>20$ to $<50 \mu \mathrm{g} / \mathrm{mL}$, potentially non activity: $\mathrm{EC}_{50}>100 \mu \mathrm{g} / \mathrm{mL}$. The selectivity index (SI), was calculated by dividing the cytotoxic and the activity using the following formula: $\mathrm{SI}=\mathrm{LC}_{50} / \mathrm{EC}_{50}$ (Coa et al., 2017).

\section{Molecular docking studies}

\section{Protein Structure and Setup}

To explore the potential mechanism of action of the hybrids $\mathbf{4 a - k}$ against two principal targets for antiparasitic drugs, the crystals structures of $P$. falciparum Lactate Dehydrogenase (pfLDH) enzyme in complex with their cofactor NADH and the structure of cruzipain, the mayor papaine-like cysteine protease in T.cruzi were obtained from the Protein Data Bank (PDB entry code 1LDG and 3I06, respectively) (Dunn et al., 1996). Discovery Studio (DS) Visualizer 2.5 was used to edit the protein structure to remove water molecules together with bound ligands. For docking studies on pfLDH in the absence of cofactor, the NADH cofactor was also removed. Both, the structures of the selected proteins were parameterized using AutoDock Tools (Morris et al., 2009). In general, hydrogens were added to polar side chains to facilitate the formation of hydrogen bonds, and the Gasteiger partial charges were calculated.

\section{Ligand dataset preparation and optimization}

Ligands used in this study are the new quinoline-hybrids 4a-k, quinoline-based drugs that have been used in the treatment of malaria (amodiaquine, mefloquine, quinine and chloroquine) and the cofactor $\mathrm{NADH}$ for comparison in the malaria-case. DS visualizer was used to rewrite the data files into pdb format. The structures of the ligands were parameterized using AutodockTools to add full hydrogens to the ligands, to assign rotatable bonds, to compute Gasteiger partial atomic charges and save the resulting structure in the required format for use with AutoDock. All possible flexible torsions of the ligand molecules were defined using AUTOTUTORS in AutoDockTools (Morris et al., 2009; Morris et al., 1998) to facilitate the simulated binding with the receptor structure.

\section{Docking and subsequent analysis}


Docking simulations were performed with AutoDock 5.6 using the Lamarkian genetic algorithm and default procedures for docking a flexible ligand to a rigid protein were followed. First, the Metapocket 2.0 server (Huang 2009) was used to identify the best candidates to protein binding pockets by predictive calculation of the topology of tertiary structures of selected subunits. According to standard program parameters, five binding pockets were calculated in the protein model and reliability of the model was reviewed through the Z-value statistical test. Second, once potential binding sites were identified, docking of ligands to these sites was carried out to determine the most probable and most energetically favorable binding conformations. For this more rigorous docking simulations involving a smaller search space limited to the identified binding site, AutodockVina (Trott and Olson 2010) was used. The exhaustiveness (internal number of repetitions) was 20 for each protein-compound pair. The active site was surrounded by a docking grid of $24 \AA 3$ with a grid spacing of $1 \AA$. In addition, five replicas per compound were calculated to obtain the final docking scores in $\mathrm{kcal} / \mathrm{mol}$. Docking solutions obtained from all molecules analyzed were ranked by the affinity scores given by AutoDock Vina based on the free energy binding theory (more negative score indicates higher affinity). Resulting structures and some of the docked conformations were graphically inspected to check the interactions using DS visualizer.

\section{Ligands drug likeness evaluation}

In silico drug-likeness prediction along with further ADMET (absorption, distribution, metabolism, excretion and toxicity) tools presents an array of opportunities which help in accelerating the discovery of new antiparasitic drugs. To find out the drug like properties 11 quinoline-hybrids 4a-k were screened for their pharmacokinetic properties using opensource cheminformatics toolkits such us Molinspiration software (for: MW, rotatable bonds and topographical polar surface area (PSA) descriptors, ALOGPS 2.1 algorithm from the Virtual Computational Chemistry Laboratory (for: Log Po/w descriptor) and Pre-ADMET 2.0 program to predicted various pharmacokinetic parameters and pharmaceutical relevant properties such as apparent predicted intestinal permeability (App. Caco-2), binding to human serum albumin (Khsa), MDCK cell permeation coefficients and intestinal or oral absorption (\%HIA, \%F). These important parameters define absorption, permeability, movement and action of drug molecule. The interpretation of two predicted ADMET properties using the Pre-ADMET program was as shown below:

Value of Caco-2 permeability is classified into three classes: 
(1) If permeability < 4, low permeability; (2) if permeability < 70, moderate permeability; and (3) if permeability $>70$, higher permeability.

Value of MDCK cell level of permeability can be classified into three classes:

(1) If permeability < 25, low permeability; (2) if $25<$ permeability < 500, moderate permeability; and (3) if permeability > 500, higher permeability.

\section{Results and Discussion}

Chemistry

The synthetic strategy for the preparation of quinoline-biphenyl hybrids is shown in Scheme 1. Thus, reaction of 8-hydroxyquinoline (1) with triflic anhydride yielded triflate $\mathbf{2}(80 \%$ yield, this compound has been already reported previously, Lord et al. 2009). Ultrasound assisted Suzuki crosscoupling reaction of compound 2 with boronic acids $3 \mathbf{a}-\mathbf{k}$ (García et al. 2019) afforded quinolinebyphenyl hybrids $4 \mathbf{a}-\mathbf{k}$ in $53-65 \%$. Other methodologies that involved microwave irradiation, long refluxing times Pierson et al. 2010), other bases (Yang et al. 2016) or solvent change (Liu et al. 2005), were used, however the results did not improve those obtained with the method described above.

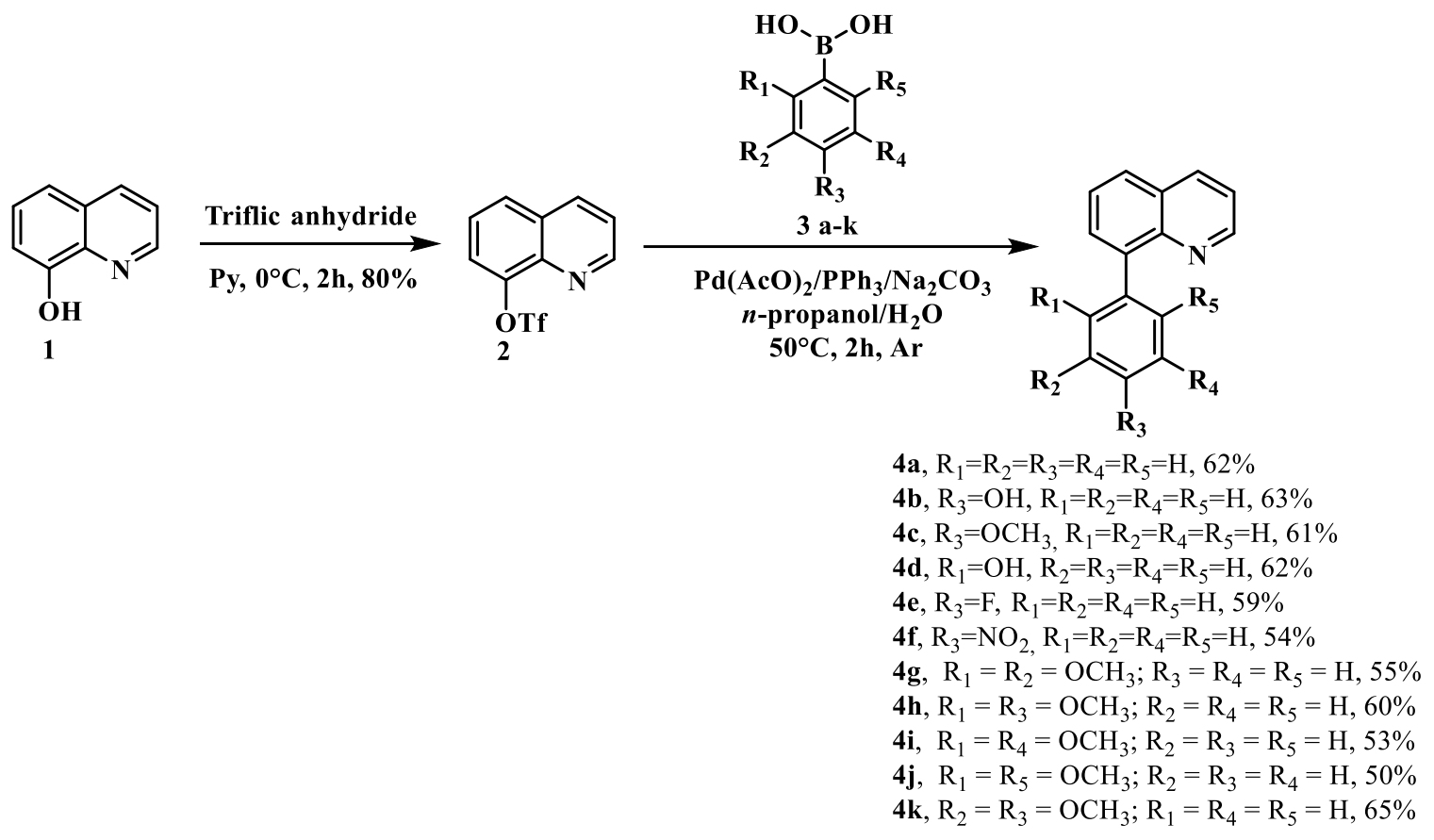

Scheme 1 Synthetic pathway to quinoline-biphenyl hybrids 
The structure of each compound was elucidated by a combined study of IR, ESI-MS, ${ }^{1} \mathrm{H}$ NMR, ${ }^{13} \mathrm{C}$ NMR and bidimensional analysis. The IR spectra exhibit characteristic absorption peaks corresponding to $\mathrm{C}=\mathrm{N}, \mathrm{C}=\mathrm{C}_{\mathrm{Ar}}, \mathrm{C}-\mathrm{O}-\mathrm{C}$ and $\mathrm{C}-\mathrm{H}_{\mathrm{Ar}}$. ESI-MS spectra exhibit characteristic $[\mathrm{M}+\mathrm{H}]^{+}$peaks corresponding to their molecular weights. The assignation of all the signals to individual $\mathrm{H}$ or $\mathrm{C}$ - atoms was based on typical $\delta$-values and $J$-constant coupling. ${ }^{1} \mathrm{H}-\mathrm{NMR}$ and ${ }^{13} \mathrm{C}-\mathrm{NMR}$ spectrum showed signals corresponding to $-\mathrm{OCH}_{3},-\mathrm{C}=\mathrm{C}-\mathrm{H}$ of aryl group and quinoline.

\section{Biological activities}

All compounds were subjected to in vitro evaluation of their cytotoxicity, antileishmanial, antitrypanosomal and antiplasmodial activity against U-937 human macrophages, intracellular amastigotes of L. (V) panamensis, intracellular amastigotes of T. cruzi and plasmodium falciparum, respectively. The results are summarized in the tables 1 and 2.

The antileishmanial, antitrypanosomal and antiplasmodial activities were measured by determining the $\mathrm{EC}_{50}$ that corresponds to the concentration of drug that gives the half-maximal reduction of the amount of parasites (Table 1). Dose-response relationship showed that compounds $\mathbf{4 a}, \mathbf{4 b}, \mathbf{4 e}, \mathbf{4 f}$ and $4 \mathbf{k}$ were active against intracellular amastigotes of $L$. $(V)$ panamensis with $\mathrm{EC}_{50}<20 \mu \mathrm{g} / \mathrm{mL}$. The most active hybrid was $4 \mathbf{a}$ an $\mathrm{EC}_{50}$ of $8.95 \pm 0.87 \mu \mathrm{g} / \mathrm{mL}$ which is comparable to referential drug meglumine antimoniate $\left(\mathrm{EC}_{50}=9.4 \pm 2.1 \mu \mathrm{g} / \mathrm{mL}\right)$. Compounds $\mathbf{4 c}, \mathbf{4 d}, \mathbf{4 h}$ and $\mathbf{4 i}$ showed a moderated activity. Finally, hybrids $\mathbf{4 g}$ and $\mathbf{4 j}$ were not active.

Table 1 In vitro antiprotozoal activity of quinoline-biphenyl hybrids

\begin{tabular}{|c|c|c|c|}
\hline \multirow[t]{2}{*}{ Compound } & $\begin{array}{l}\text { Antileishmanial activity } \\
\qquad(\mu \mathrm{g} / \mathrm{mL}, \mu \mathrm{M})\end{array}$ & $\begin{array}{c}\text { Antitrypanosomal activity } \\
(\mu \mathrm{g} / \mathrm{mL}, \mu \mathrm{M})\end{array}$ & $\begin{array}{c}\text { Antiplasmodial activity } \\
(\mu \mathrm{g} / \mathrm{mL}, \mu \mathrm{M})\end{array}$ \\
\hline & $\mathrm{EC}_{50}{ }^{\mathrm{a}}$ & EC50 & $\mathbf{E C}_{50}$ \\
\hline $4 a$ & $8.95 \pm 0.87,43.62$ & $32.68 \pm 3.79,159.19$ & $21.61 \pm 2.48,105.30$ \\
\hline $4 b$ & $15.34 \pm 2.70,69.34$ & $8.84 \pm 0.94,39.96$ & $32.52 \pm 1,05,146.97$ \\
\hline $4 c$ & $33.63 \pm 1.85,142.91$ & $186.69 \pm 13.26,793.46$ & $30.44 \pm 3.40,129.38$ \\
\hline $4 d$ & $25.27 \pm 5.22,114.05$ & $34.62 \pm 5.51,156.24$ & $15.25 \pm 1.39,68.83$ \\
\hline $4 e$ & $17.01 \pm 1.50,76.19$ & $34.50 \pm 3.94,154.53$ & $15.72 \pm 2.62,70.40$ \\
\hline $4 f$ & $13.86 \pm 1.79,55.39$ & $50.19 \pm 8.39,200.55$ & $12.40 \pm 1.19,49.53$ \\
\hline
\end{tabular}




\begin{tabular}{cccc}
$\mathbf{4 g}$ & $127.85 \pm 50.85,481.88$ & $74.91 \pm 8.54,282.33$ & $58.40 \pm 5.13,220.11$ \\
$\mathbf{4 h}$ & $26.46 \pm 0.29,99.72$ & $75.45 \pm 8.57,284.38$ & $20.78 \pm 2.86,78.32$ \\
$\mathbf{4 i}$ & $41.27 \pm 2.98,155.57$ & $45.69 \pm 5.18,172.23$ & $31.90 \pm 5.97,120.23$ \\
$\mathbf{4 j}$ & $100.96 \pm 98.41,380.55$ & $35.94 \pm 3.78,135.47$ & $51.65 \pm 5.80,194.69$ \\
$\mathbf{4 k}$ & $16.26 \pm 1.67,61.30$ & $17.88 \pm 0.97,67.38$ & $11.33 \pm 1.07,42.70$ \\
$\begin{array}{c}\text { Meglumine } \\
\text { antimoniate } \\
\text { Amphotericin B }\end{array}$ & $9.4 \pm 2.1,25.68$ & $\mathrm{NA}^{\mathrm{c}}$ & $\mathrm{NA}^{\mathrm{c}}$ \\
$\begin{array}{c}\text { Benznidazole } \\
\text { Chloroquine }\end{array}$ & $0.05 \pm 0.01,0.054$ & $\mathrm{NA}^{\mathrm{c}}$ & $\mathrm{NA}^{\mathrm{c}}$ \\
\hline
\end{tabular}

Data represent mean value +/- standard deviation; ${ }^{\mathrm{a}} \mathrm{EC}_{50}$ : Effective Concentration 50; ${ }^{\mathrm{b}}$ The molecular weight (MW) of MA is $365.98 \mathrm{~g} / \mathrm{mol}$ (PubChem Compound Database, CID 64953, National Center for Biotechnology Information) (pubchem.ncbi.nlm.nih.gov/summary/summary.cgi?cid=64953); ${ }^{\mathrm{c}} \mathrm{NA}$ : Not applicable. Active compounds: $\mathrm{EC}_{50}<20 \mu \mathrm{g} / \mathrm{mL}$.

Compounds $\mathbf{4 b}$ and $\mathbf{4 k}$ were active against intracellular amastigotes of $T$. cruzi. Hybrid $\mathbf{4 b}$ showed an activity similar to benznidazole ( $\mathrm{EC}_{50}=8.84 \pm 0.94 \mathrm{vs} 10.5 \pm 1.8 \mu \mathrm{g} / \mathrm{mL}$, respectively). Molecules $\mathbf{4 a}, \mathbf{4 d}, \mathbf{4 e}$ and $\mathbf{4 j}$ exhibited moderated antitrypanosomal activity. In the same way, we observed that the compounds with higher activity against $P$. falciparum were $\mathbf{4 d - 4 f}$ and $\mathbf{4 k}$, being the hybrid $\mathbf{4 k}$ the most active with an $\mathrm{IC}_{50}$ of $11.33 \pm 1.07 \mu \mathrm{g} / \mathrm{mL}$.

Compounds $\mathbf{4 a}, \mathbf{4 b}, \mathbf{4 d - 4 f}, \mathbf{4 i - 4 k}$ and amphotericin B showed highly cytotoxic to U-937 cells showing $\mathrm{LC}_{50}<100 \mu \mathrm{g} / \mathrm{mL}$. Hybrids $\mathbf{4 c}, \mathbf{4 g}, \mathbf{4 h}$ and benznidazole, exhibited moderate cytotoxicity evidenced by $\mathrm{LC}_{50}$ values higher than $100 \mu \mathrm{g} / \mathrm{mL}$. In turn, meglumine antimoniate showed no cytotoxicity $\left(\mathrm{LC}_{50}>\right.$ $200.0 \mu \mathrm{g} / \mathrm{mL}$ ) (Table 2).

Overall, the anti-protozoal activity of the compounds was higher than their cytotoxicity. Thus, the calculated SI (Selectivity Index) values for these hybrids were $>1$. As demonstrated elsewhere, amphotericin B and meglumine antimoniate have very high SI values. Although hybrids $\mathbf{4 a}, \mathbf{4 b}$ and $\mathbf{4 k}$ showed activity comparable to that of meglumine antimoniate, benznidazole and chloroquine, respectively, the SI of these compounds is affected by their high cytotoxicity. These results suggest that the biological activity of the quinoline derivatives reported here, except for $\mathbf{4 g}$ and $\mathbf{4 j}$, is selective and 
more active against $L$. (V) panamensis than U-937 cells. Compounds $\mathbf{4 b}, \mathbf{4 d}, \mathbf{4 e}$ and $\mathbf{4 g - 4 \mathbf { i }}$ were more actives against $T$. cruzi parasites than U-937 cells. On the other hand, hybrids $\mathbf{4 a}, \mathbf{4} \mathbf{c}-\mathbf{4 i}$ and $\mathbf{4 k}$, showed selectivity against $P$. falciparum. In this sense, compound $\mathbf{4 h}$ exhibited the best SI on both $L$. (V) panamensis and P. falciparum, with 4.78 and 6.08 values, respectively (Table 2).

Table 2 In vitro cytotoxicity and selectivity index of biphenyl hybrids

\begin{tabular}{|c|c|c|c|c|}
\hline Compound & $\begin{array}{c}\text { Cytotoxicity } \\
(\mathrm{U}-937 \text { cells) } \\
(\mu \mathrm{g} / \mathrm{mL}, \mu \mathrm{M})\end{array}$ & $\begin{array}{c}\text { L. }(V) \\
\text { Panamensis }\end{array}$ & T. Cruzi & P. falciparum \\
\hline & $\mathbf{L C}_{50}{ }^{a}$ & $\mathbf{S I}^{\mathbf{b}}$ & SI & SI \\
\hline $4 a$ & $27.31 \pm 8.64,5.61$ & 3.05 & 0.83 & 1.26 \\
\hline $4 b$ & $20.39 \pm 4.33,92.14$ & 1.33 & 2.31 & 0.63 \\
\hline $4 c$ & $133.11 \pm 32.78,565.75$ & 3.96 & 0.71 & 4.37 \\
\hline $4 d$ & $42.93 \pm 5.25,193.72$ & 1.70 & 1.24 & 2.81 \\
\hline $4 e$ & $62.91 \pm 22.55,281.81$ & 3.70 & 1.82 & 4.0 \\
\hline $4 f$ & $28.07 \pm 0.89,112.16$ & 2.02 & 0.56 & 2.26 \\
\hline $4 g$ & $120.39 \pm 20.76,453.76$ & 0.94 & 1.60 & 2.06 \\
\hline $4 h$ & $126.51 \pm 16.18,476.84$ & 4.78 & 1.68 & 6.08 \\
\hline $4 \mathbf{i}$ & $67.30+15.40,253.67$ & 1.63 & 1.47 & 2.1 \\
\hline $\mathbf{4 j}$ & $22.24 \pm 1.50,83.81$ & 0.22 & 0.61 & 0.43 \\
\hline $4 k$ & $16.38 \pm 3.71,61.76$ & 1.01 & 0.72 & 1.44 \\
\hline $\begin{array}{c}\text { Meglumine } \\
\text { antimoniate }^{c}\end{array}$ & $416.4 \pm 66.6 ; 1137.80$ & 44.3 & $\mathrm{NA}^{\mathrm{d}}$ & $\mathrm{NA}^{\mathrm{d}}$ \\
\hline Amphotericin B & $42.1 \pm 2.0,45.6$ & 842 & $\mathrm{NA}^{\mathrm{d}}$ & $\mathrm{NA}^{\mathrm{d}}$ \\
\hline Benznidazole & $179.0 \pm 4.2,687.8$ & $\mathrm{NA}^{\mathrm{d}}$ & 17.0 & $\mathrm{NA}^{\mathrm{d}}$ \\
\hline
\end{tabular}


Data represent mean value $+/-$ standard deviation; ${ }^{\mathrm{a}} \mathrm{LC}_{50}$ : Lethal Concentration $50 ;{ }^{\mathrm{b}} \mathrm{SI}$ : Selectivity $\mathrm{Index}=\mathrm{LC}_{50} / \mathrm{EC}_{50}$; ${ }^{\mathrm{c}}$ The molecular weight (MW) of MA is $365.98 \mathrm{~g} / \mathrm{mol}$ (PubChem Compound Database, CID 64953, National Center for

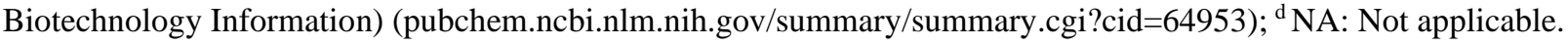

SAR analysis showed that $\mathbf{4 a}$, bearing an unsubstituted phenyl group, was the most active in $L$. $(V)$ panamensis. Compound $\mathbf{4 b}$, with a hydroxyl group in the 4-position is most active than compound $\mathbf{4 c}$ with a methoxy instead of the hydroxy group. The activity decreases when the hydroxy group was changed from 4-position to 2-position (4b vs 4d). Electron withdrawing groups in 4-position increase the activity over the electron donating methoxy group (4e and $\mathbf{4 f} v s \mathbf{4 c}$ ).

As regards $T$. cruzi, we found that $\mathbf{4 b}$ was the most active compound. Changing the position of the hydroxyl group (4d) or the presence of electron withdrawing groups (4e and 4f) decrease the activity. The methylation of the hydroxyl group (4c) leads to the loss of activity. These results agree with other reports for several chalcones, coumarins, cinnamic ester and triclosan-caffeic acid hybrids (Brenzan et al. 2008; Aponte et al. 2010; Otero et al. 2014; Otero et al. 2017; García et al. 2018). The effect of the hydroxyl groups may be due to a better molecular recognition ability towards target bioreceptors upon hydrogen bond formation (Patrick 2013). In both protozoal disease, all disubstituted hybrids, with exception of $\mathbf{4 k}$, exhibited low activity. Overall, monosubstituted compounds (4a-4f) showed better activity than disubstituted hybrids $(\mathbf{4 g}-\mathbf{4} \mathbf{j})$

On the other hand, we found that the presence of methoxyl groups in 3-and 4- position (4k) is very important for the antiplasmodial activity. This activity decreased when the methoxyl groups were changed to 2,4- (4h), 2,5-(4i), 2,6-(4i) and 2,3-(4g) positions. The activity is also related to the presence in 4-position of electron withdrawing groups, such as nitro and fluorine groups, and the presence of the hydroxyl electron donating group in 2-position, as it appears in compound 4d. Electron donating groups, hydroxyl and methoxyl groups in the 4-position, such as in $\mathbf{4 c}$ and $\mathbf{4 d}$, lead to a decrease in activity.

Docking studies against PfLDH structure and binding pose prediction 
The $P$. falciparum lactate dehydrogenase enzyme $(P f L D H)$ has been is considered as a potential molecular target for antimalarials, since it is a key enzyme that catalyses the interconversion of pyruvate and lactate with concomitant interconversion of $\mathrm{NADH}$ and $\mathrm{NAD}^{+}$and provides the energy for the survival of the parasite. One of the products of hemoglobin degradation by malarial parasites is the ferriprotoporphyrin IX (hematin), which intoxicates the parasite by competing with NADH for the active site of PfLDH. Parasite survival depends on polymerization of hematin to hemozoin. The quinoline derivatives are believed to form complexes with the dimeric hematin, preventing the formation of hemozoin (Egan and Ncokazi 2005). Our present work used docking studies to select potential inhibitors of PfLDH based on quinoline hybrids as ligands, which were in vitro tested for its antimalarial activity against $P$. falciparum. Thus, docking studies are carried out to investigate the intermolecular interactions between the active ligands and the receptor PfLDH. The PfLDH enzyme possesses two important binding pockets, the cofactor (NADH) binding pocket (Site $\mathbf{A})$ the allosteric binding pocket and (Site B). Using the Metapocket server, two potential binding sites for each ligand have been identified, one of them resulted in the NADH-binding site. This Site $\mathbf{1}$ is a binding pocket on the $N$-terminal end of the enzyme comprising amino acid residues Gly27, Ser28, Gly29, Phe52, Asp53, Ile54, Thr97, Ala98, Gly99, Phe100, Thr139, and Asn140. Site 2 was identified as the allostericbinding pocket near the surface end of enzyme constituted by amino acid residues Asp230, Lys198, Val233, Lys314, Glu317, Asp230, Leu201, Glu226, Phe229, Val200, Leu237, and Asn241 (fig. 3).

Then, the 11 hybrids of quinoline were docked, with the cofactor absent, into both active sites of PfLDH (PDB code 1LDG) using AutoDock Vina.
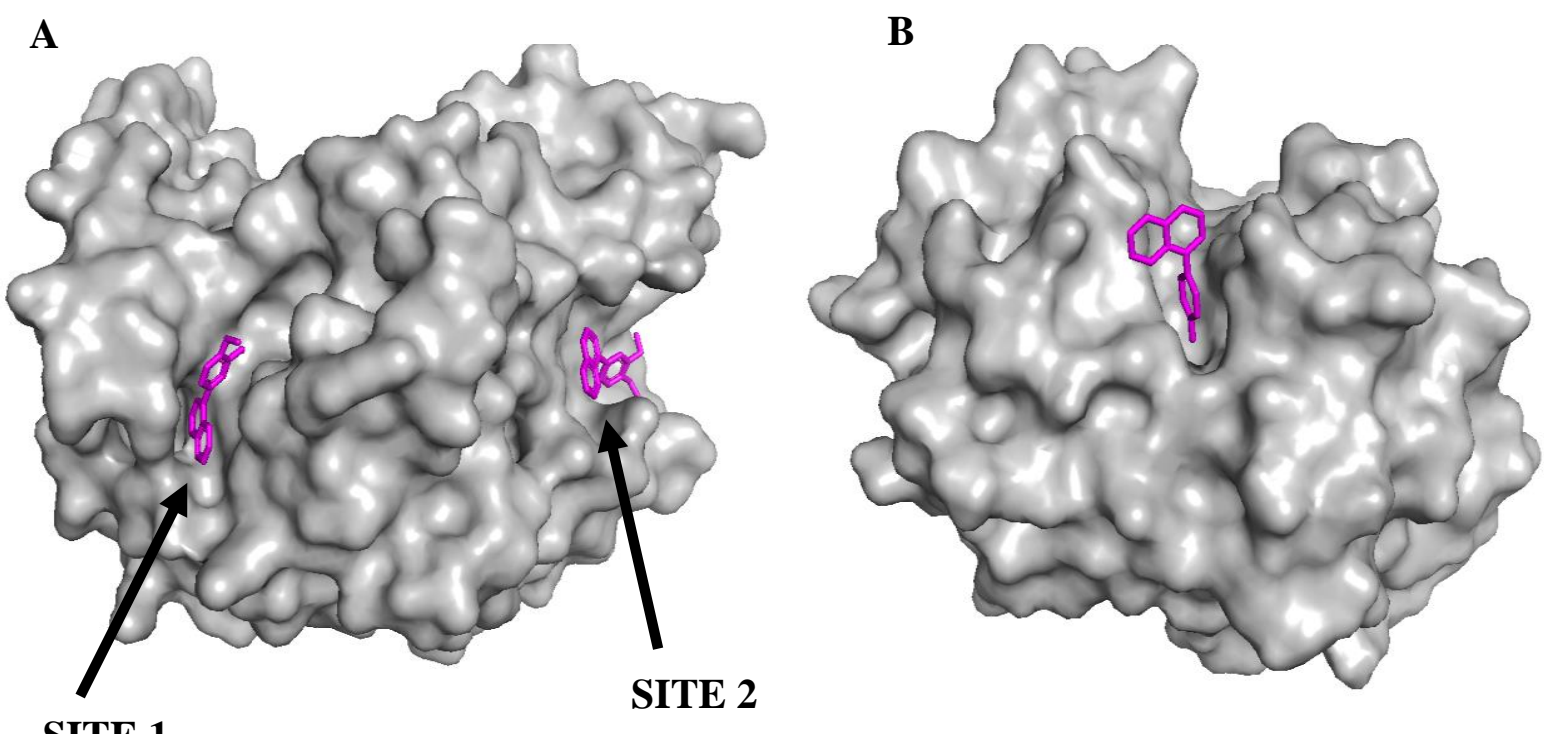

SITE 1 
Fig.3 (A) Shows the most active compound against malaria parasite 4k (in red) in the two binding surface sites present in PfLDH enzyme: Site 1 is the natural NADH-binding site and Site 2 refers to the potential allosteric binding site. (B) Shows the most active compound $\mathbf{4 b}$ against $T$. cruzi parasite in the best binding site of $T$. cruzi cruzipain.

When the cofactor was absent a comparable binding within the NADH-binding site and the allosteric site was achieved for all ligands, showing that the NADH-binding pocket (Site 1) was the preferred binding site for all the ligands studied. The most active compound $4 \mathbf{k}\left(\mathrm{CE}_{50}: 11.33 \mu \mathrm{g} / \mathrm{mL}\right.$, Malaria parasite) fitted well in the NADH pocket (Docking score of $-7.7 \mathrm{kcal} / \mathrm{mol}$ ) and showed the best docking energy values among all hybrids, that is, close to NADH (which has a docking energy of -9.4 $\mathrm{kcal} / \mathrm{mol}$ ). For comparison, docking score affinities against $P f \mathrm{LDH}$ structure for four quinoline-based market drugs (inhibitors used for malaria treatment) were also calculated in this study. It has been shown that the chloroquine interacts specifically with $P f \mathrm{LDH}$ in the NADH binding site, occupying a position analogous to that of the adenyl ring cofactor and therefore acts as a competitive inhibitor, suggesting that the mechanism of parasite growth inhibition by the different compounds results from drug competition with NADH for the PfLDH (Read et al. 1999; Vennerstrom et al. 1999; Menting et al. 1997). For all hybrids studied, there was comparable docked solutions within the cofactor-binding site similar to that of drugs currently used. In the absence of the cofactor, the most stable bound conformation of the hybrid $\mathbf{4 k}$ (the docking score was $-7.7 \mathrm{kcal} / \mathrm{mol}$ ) showed higher affinity than that observed for the marketed drugs chloroquine, amodiaquine and quinine (docking energy of -7.4, -7.4 and $-7.1 \mathrm{kcal} / \mathrm{mol}$, respectively). The binding energies for representative ligand structures, as calculated by Autodock, are given in Table 3. The superposition of NADH (in blue) and the best conformation obtained theoretically for all hybrids (in red), shown in Figure 1, reveals that ligands endowed with conformational mobility (calculated in this docking study) can rearrange themselves into favorable conformations in order to fill the cofactor-binding site.

All ligands studied showed good binding affinity compared to NADH in the NADH-binding pocket pointing to a possible competitive inhibition. In general, the compounds docked similarly across the delimited binding site, with a set of hydrophobic interactions that potentially confers stability during the binding event. The molecules also form diverse types of interactions, especially $\pi$-anion between aryl ring of hybrids and carboxylic group of Asp53 residue in the protein, $\pi$-sigma interaction between 
aromatic quinoline ring and the catalytic residues Ala98 and Ile54, located adjacent to the nicotinamide end of the cofactor-binding domain. The best docked conformation of highly active molecule (compound 4k) and the active site residues that interact inside $P f L D H$ are shown in Figure 4A and Figure 4B. According to these docking results, PfLDH could be a potential therapeutic target for the evaluated hybrids, despite the fact that the docking scores when compared to natural ligand NADH showed highest binding values than the typical antimalarial-drugs. In addition, docking studies showed that the affinity of the designed hybrids is correlated with the results obtained from in-vitro studies.

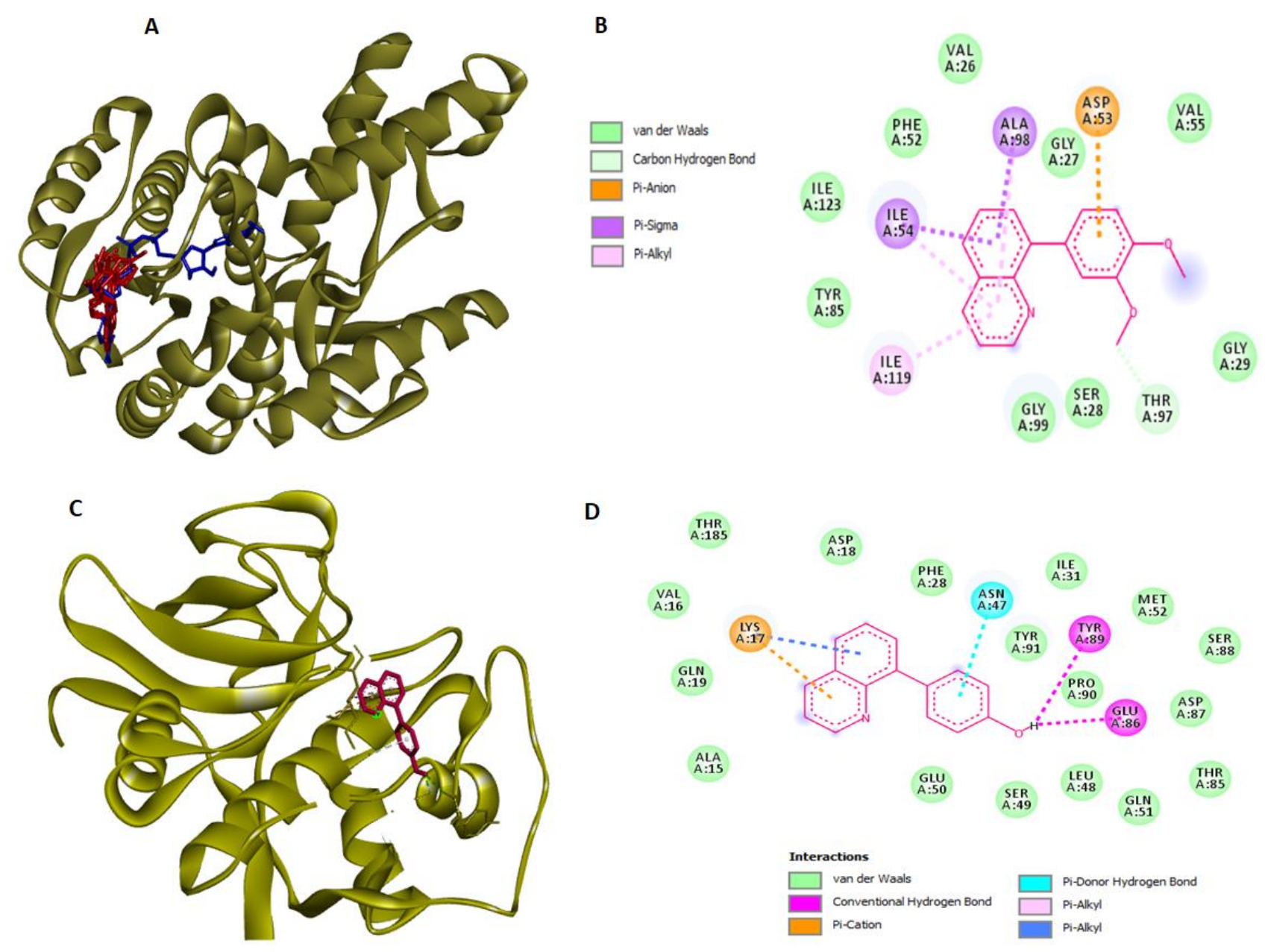

Fig 2 (A) Superposition of the best conformation of a set hybrids 4a-k (in red) and NADH (in blue) in the NADH-binding site of $P$. falciparum lactate dehydrogenase (PfLDH enzyme PDB: 1LDG). (B) 2D representation of interactions formed by the most active compound against malaria parasite $\mathbf{4 k}$ with aminoacids of the enzyme. (C) The best conformation of the most active hybrid against $T$. cruzi parasite $4 \mathbf{b}$ (in red) within active site of $T$. cruzi cruzipain structure (PDB:3I06). (D) 2D representation of interactions formed by the most active compound against $T$. cruzi parasite $\mathbf{4} \mathbf{b}$ with aminoacids of the cruzipain enzyme. 


\section{Docking of hybrids on Cruzipain active site and binding pose prediction}

Cysteine proteases are essential for T. cruzi survival. Among them, cruzipain is a relevant protein target to design novel inhibitors for Chagas disease treatment (Otto and Shirmeister 1997; Sajid and McKerrow 2002). This enzyme hydrolyzes chromogenic peptides at arginine or lysine carboxyl terminals and plays a key role in the development and differentiation of the parasite during various life cycle stages (Beaulieu et al. 2010). In order to investigate the specific interactions from each ligand with Cruzipain (PDB: 3I06), we first identify the best pockets calculated from Metapocket server. The data-set suggested that the highest docking score resulted when the pocket used is characterized by the presence of amino acids residues: Lys17, Phe28, Glu50, Asp18, Asn47, Leu48, Ser49, Glu86, Asp87, Pro90, Tyr91, Ala15, Gln19, Val16, Thr185, Asp18, Ile31, Met52, Ser88, Thr85, Gln51 and Tyt89

(Figure 1B). These amino acids residues were near to the enzyme surface. This site was defined as binding pocket for the docking runs.

Molecular docking studies were performed on all hybrids $\mathbf{4 a - k}$, to investigate the importance of the motif that contribute to T. cruzi cruzipain binding when docked into the selected pocket. All quinolineligands showed similar binding affinities for the selected pocket (Table 3). Notably, the most active compound $\mathbf{4 b}$ showed the highest scoring pose (binding energy of $-7.5 \mathrm{kcal} / \mathrm{mol}$ ). The results from the docking analyses suggest a slowly reversible mechanism of inhibition that is aided by strong noncovalent interactions. In general, the compounds docked showed the formation of significant interactions with residues within the binding pocket. Then, a closer look at the best possible binding pose of hybrid $\mathbf{4 b}$ (highly active molecule, $\mathrm{CE}_{50}: 8.84 \mu \mathrm{g} / \mathrm{mL}$ ) reveals that strong interactions into the active site, which are shown in Figure 4C, involved one hydrogen bond interaction between hydroxyl group of $\mathbf{4 b}$ and the Tyr89 and Glu86 residues; $\pi$-cation between Lys17 residue of the protein and the quinoline-ring motif of the compound. Hydrophobic interactions surrounded by side chains of predominantly nonpolar residues confers stability during the binding event in the pocket (Figure 4D). Table 3 summarizes the best binding energy per evaluated compound on T. cruzi cruzipain. Docking 
results suggest that hybrid $\mathbf{4 b}$ represents a novel hit cruzipain inhibitor that can be exploited for further analog design as potential antichagasic agents. Moreover, these findings are also supported by previous reports of active quinolines against this parasite protein target (Kaur et al 2010; Foley and Tilley 1998).

Table 3 Best binding energy (in $\mathrm{kcal} / \mathrm{mol}$ ) of most favorable docked conformations based on AutoDock scoring.

\begin{tabular}{|c|c|c|c|}
\hline \multirow{3}{*}{ Ligand } & \multicolumn{2}{|c|}{ PfLDH } & \multirow{3}{*}{$\begin{array}{c}\text { T. cruzi cruzipain } \\
\text { Best binding energy } \\
\text { (kcal/mol) }\end{array}$} \\
\hline & \multicolumn{2}{|c|}{ Best binding energy (kcal/mol) } & \\
\hline & Site $1^{a}$ & Site $2^{b}$ & \\
\hline $4^{\mathrm{a}}$ & -7.5 & -6.6 & -7.2 \\
\hline $4 b$ & -7.5 & -6.3 & -7.5 \\
\hline $4 c$ & -7.3 & -6.5 & -7.1 \\
\hline 4d & -7.4 & -6.6 & -7.2 \\
\hline $4 e$ & -7.6 & -6.7 & -7.2 \\
\hline $4 f$ & -7.6 & -6.5 & -7.1 \\
\hline $4 \mathrm{~g}$ & -7.1 & -6.4 & -6.8 \\
\hline 4h & -7.5 & -6.3 & -6.9 \\
\hline $4 \mathbf{i}$ & -7.3 & -6.2 & -6.9 \\
\hline $4 \mathbf{j}$ & -6.9 & -6.5 & -6.9 \\
\hline $4 \mathbf{k}$ & -7.7 & -6.5 & -6.9 \\
\hline NADH & -9.7 & N/A & --- \\
\hline Chloroquine & -7.4 & -6.3 & --- \\
\hline Amodiaquine & -7.4 & -6.8 & --- \\
\hline Quinine & -7.1 & -6.5 & --- \\
\hline Mefloquine & -8.3 & -7.5 & --- \\
\hline
\end{tabular}

\section{Drug-likeness prediction studies}

We calculated and analyzed various drug-likeness properties for the 11 quinoline-biphenyl hybrids. The prediction results are summarized in Table 4. All compounds showed typical values for the parameters analyzed, exhibiting suitable drug like characteristics. The predicted values are within the range of properties of 95\% of currently known drugs. According to Lipinski's rule of five (Lipinski et al. 1997, an orally active drug that has no more than one violation is acceptable) the tested hybrids 4a-k could be orally active drugs in human. It was observed that all the title compounds exhibited high human intestinal absorption (\% HIA) and high percent of human oral absorption (\% F) ranging from 80 
to $100 \%$. Greater HIA and F values denote that the hybrids $\mathbf{4 a - k}$ could be better absorbed from the intestinal tract upon oral administration. Among the predicted physico-chemical properties, the molecular PSA is a descriptor that was shown to correlate well with passive molecular transport through membranes and allows the prediction of drug-membrane interactions. Calculated PSA (Ertl et al. 2000) values for compounds 4a-k showed high PSA values, suggesting that perhaps these polar compounds tend to have a greater affinity and good ability to penetrate through infected cells.

Tabla 4 Physico-chemical and drug-like properties of compounds $\mathbf{4 a - k}$

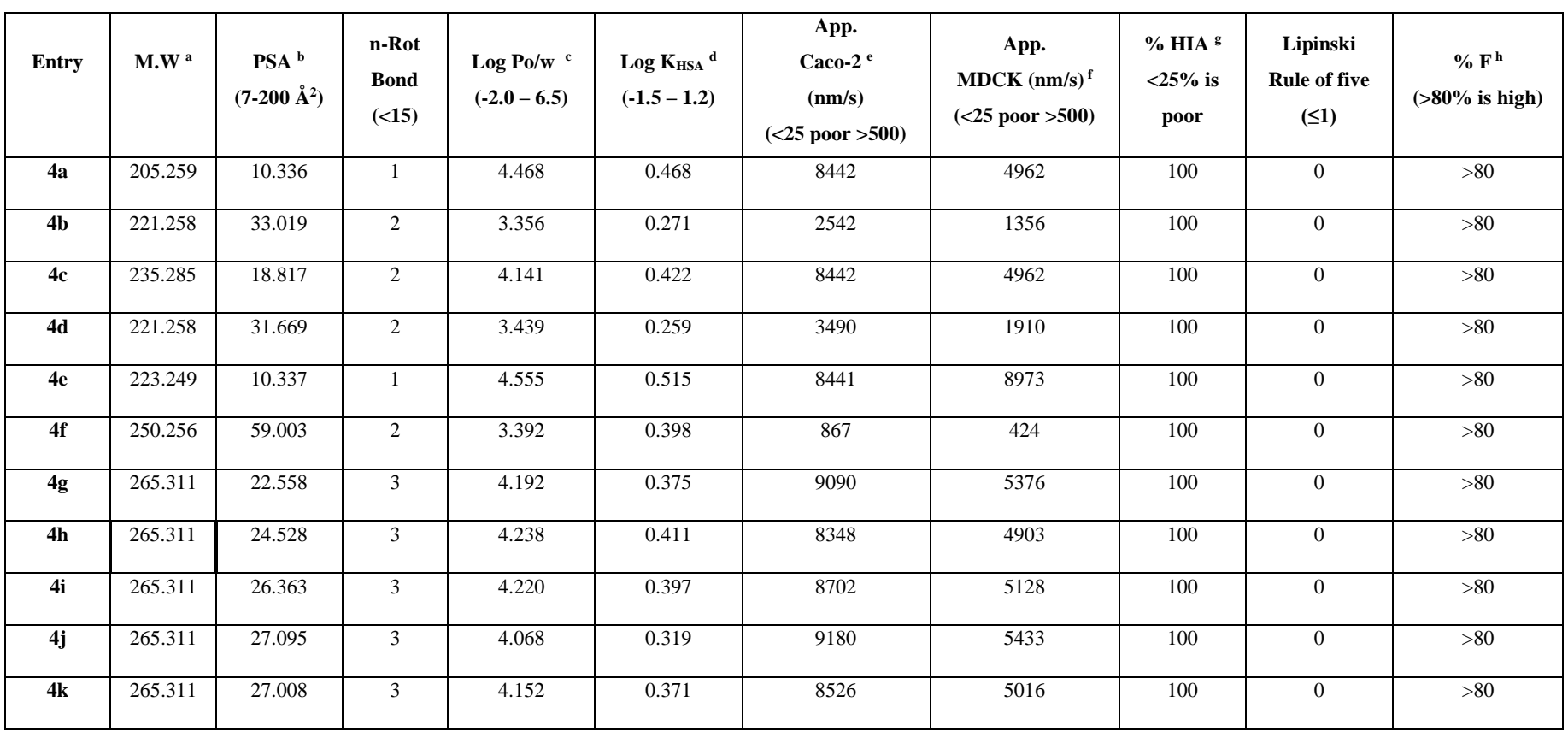

${ }^{\mathrm{a}}$ Molecular weight of the molecule; ; ${ }^{\mathrm{b}}$ Polar surface area (PSA) (7.0-200.0); ${ }^{\mathrm{c}}$ Predicted octanol-water partition coefficient (log Po/w) (-2.0 to 6.5); ${ }^{\mathrm{d}}$ Logarithm

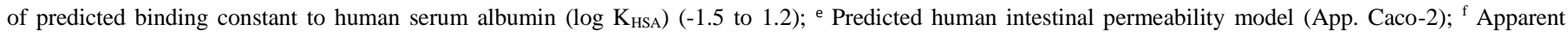
permeability across cellular membranes of Madin-Darby canine kidney (MDCK) cells; ${ }^{\mathrm{g}}$ Human intestinal absorption (\% HIA) (>80\% is high, <25\% is poor); ${ }^{\mathrm{h}}$ is the fraction of an oral administered drug that reaches systemic circulation (percent of human oral absorption \% F).

In addition, lipophilicity influences a number of physiological properties, including transport through lipid bilayers, and therefore it is an important property that a drug should exhibit. LogP gives a measure of the lipophilicity of a compound and is a good indicator of permeability across the cell wall (Veber et al. 2002). In this study, all the tested compounds exhibited LogP values below 5, ranging from 3.346 to 4.555, suggesting good permeability and permeation across the cell membrane of infected cells. Moreover, in silico artificial membrane permeation rate across Caco-2 cell monolayers or MDCK cells was calculated for all quinoline-hybrids derivatives. It was found that the passive transmembrane 
permeation of the novel compounds displayed good permeability values (from 1356 to $9180 \mathrm{~nm} / \mathrm{s}$ ), except for nitro-substituted $4 \mathbf{f}$ which displayed poor cell permeability values (less than $867 \mathrm{~nm} / \mathrm{s}$ ). Finally, the early prediction of plasma protein binding (calculated as log $\mathrm{K}_{\mathrm{HSA}}$ ) has vital importance in the characterization of drug distribution in the systemic circulation. Unfavorable log $\mathrm{K}_{\mathrm{HSA}}$ values can represent a negative effect on clinical development of promising drug candidates for human parasitic diseases chemotherapy. For all compounds, were obtained high binding affinity values (more than 0.25 ) compared to reference values taken from $95 \%$ of currently known drugs ( $\log \mathrm{K}_{\mathrm{HSA}}$ from -1.5 to 1.2).

From the therapeutic point of view, the interpretation of predicted ADMET properties showed recommended values ranges for an ideal drug, demonstrating the potential of the hybrids $\mathbf{4 a - k}$ as therapeutic candidates to discover novel drugs for specific treatment for T. cruzi or P. falciparum infections. These in-silico ADMET predictions suggest that quinoline-biphenyl hybrids here reported follow the criteria for orally active drugs and thus represent a potential pharmacologically active framework that should be considered in progressing further potential hits.

\section{Conclusions}

The synthesis, in silico studies, antileishmanial, antitrypanosomal and antiplasmodial screening of eleven quinoline-biphenyl hybrids are reported. Five of them were active against L. (V) panamensis, two of them against $T$. cruzi and four of them against $P$. falciparum with EC 50 values lower than 20 $\mu \mathrm{g} / \mathrm{mL}$. Hybrid 4a showed similar activity than meglumine antimoniate and compound $\mathbf{4 b}$ exhibited an activity similar to that of benznidazole. Hybrid $\mathbf{4 k}$ showed the best activity against P. falciparum. Studies on an animal model are needed to confirm the results observed in vitro. These compounds were toxic for mammalian U-937 cells, however they may still have potential to be considered as candidates for antileishmanial, antitrypanosomal and antiplasmodial drug development. More studies on toxicity using other cell lines are needed to discriminate whether the toxicity shown by these compounds is specific against tumor or non-tumor cells. SAR study revealed the importance of hydroxyl group in 4-position of the phenyl group for antitrypanosomal activity. On the other hand, for antileishmanial activity the presence of substituents in the phenyl group decrease de activity. As regards antiplasmodial activity, our studies have shown that the presence of methoxyl groups in 3- and

4-position and electron withdrawing groups in the 4-position are important in order to achieve biological action. 
Molecular docking was used to investigate the in silico inhibition effects of the eleven quinolinebiphenyl hybrids on two important antiparasitic drug targets (PfLDH and T. cruzi cruzipain enzymes). Docking studies against PfLDH structure suggest that the hybrids could act as competitive inhibitors as they had higher binding energy than reference drugs, and close to the cofactor, NADH. In addition, the present findings further support that these molecules may be potentially inhibitors of $T$. cruzi cruzipain enzyme and could be a potential molecular target for the evaluated compounds. Physicochemical and ADMET profile of these molecules, such as polar Surface area (PSA), LogP and the number of rotatable bonds (Nrot), membrane permeation rate, Plasma Protein Binding (KHSA) and human oral absorption $(\% \mathrm{~F})$ showed that these hybrids have potential for an eventual development as oral agents and can be significant active drug candidates in search of better and safe antiprotozoal agents.

\section{Acknowledgments}

The authors thank Universidad de Antioquia (grant CODI IN656CE and CIDEPRO) for financial support.

\section{Conflict of interest}

The authors declare no conflict of interest.

\section{Supplementary data}

Supplementary data associated with this article can be found, in the online version 


\section{References}

Alvar J, Vélez ID, Bern C, Herrero M, Desjeux P, Cano J, Jannin J, den Boer M (2012) Leishmaniasis

Worldwide and Global Estimates of Its Incidence. PLOS One 7: e35671

Aponte J, Castillo D, Estevez Y, Gonzalez G, Arevalo J, Hammonda G, Sauvain M (2010). In vitro and in vivo anti-Leishmania activity of polysubstituted synthetic chalcones. Bioorg Med Chem Lett 20:100-103.

Beaulieu C, Isabel E, Fortier A, Massé F, Mellon C, Méthot N, Black WC (2010). Identification of potent and reversible cruzipain inhibitors for the treatment of Chagas disease. Bioorg Med Chem Let 20:7444-7449.

Brenzan MA, Vaturu C, Dias B, Ueda T, Young MC, Côrrea AG, Alvim J Jr, dos Santos AO, Cortez DA (2008). Structure-activity relationship of (-) mammea A/BB derivatives against Leishmania amazonensis. Biomed Pharmacother 62:651-658.

Brun R, Bühler Y, Sandmeier U, Kaminsky R, Bacchi CJ, Rattendi D, Lane S, Croft SL, Snowdon D, Yardley V, Caravatti G, Frei J, Stanek J, Mett H (1996). In Vitro Trypanocidal Activities of New SAdenosylmethionine Decarboxylase Inhibitors. Antimicrob Agents Chemother 40:1442-1447

Cardona-G W, Yepes AF, Herrera-R A (2018). Hybrid Molecules: Promising Compounds for the Development of New Treatments Against Leishmaniasis and Chagas Disease. Curr Med Chem 25:3637-3679

Cardona W, Arango V, Domínguez J, Robledo S, Muñoz D, Figadère B, Velez ID, Sáez J (2013). Synthesis and leishmanicidal activity of new bis-alkylquinolines. J Chil Chem Soc 58:1709-1712.

Chatelain E, Ioset JR (2011). Drug discovery and development for neglected diseases: the DNDi model. Drug Des Devel Ther 16:175-181.

Chen M, Zhai L, Christensen SB, Theander TG, Kharazmi A (2001). A Inhibition of fumarate reductase in Leishmania major and L. donovani by chalcones. Antimicrob. Agents Chemother 45:2023-2029 
Coa JC, Castrillón W, Cardona W, Carda M, Ospina V, Muñoz JA, Vélez ID, Robledo SM (2015). Synthesis, leishmanicidal, trypanocidal and cytotoxic activity of quinoline-hydrazone hybrids. Eur J Med Chem 101:746-753.

Coa JC, García E, Carda M, Agut RD, Vélez ID, Muñoz JA, Yepes LM, Robledo SM, Cardona WI (2017). Synthesis, leishmanicidal, trypanocidal and cytotoxic activities of quinoline-chalcone and quinoline-chromone hybrids. Med Chem Res 26:1505-1414.

García E, Ochoa R, Vásquez I, Conesa-Milián L, Carda M, Yepes A, Vélez ID, Robledo SM, Cardona-GW (2019). Furanchalcone-biphenyl hybrids: synthesis, in silico studies, antitrypanosomal and cytotoxic activities. Med Chem Res 28:608-622.

García E, Coa JC, Otero E, Carda M, Vélez ID, Robledo SM, Cardona WI (2018). Synthesis and antiprotozoal activity of furanchalcone-quinoline, furanchalcone-chromone and furanchalconeimidazole hybrids. Med Chem Res 27:497-511.

Den Boer M, Argaw D, Jannin J, Alvar J (2011). Leishmaniasis impact and treatment access. Clin Microbiol Infect 17:1471-1477.

Dietze R, Carvalho SF, Valli LC, Berman J, Brewer T, Milhous W, Sanchez J, Schuster B, Grogl M (2001). Phase 2 trial of WR6026, an orally administered 8-aminoquinoline, in the treatment of visceral leishmaniasis caused by Leishmania chagasi. Am J Trop Med Hyg 65:685-689.

Dunn C, Banfield M, Barker j, Higham C, Moreton K, Turgut-Balik D, Brady R, Holbrook JJ (1996). The Structure of Lactate Dehydrogenase from Plasmodium falciparum Reveals a New Target for Anti-Malarial. Design. Nat. Struct. Mol. Biol 3:912-915.

Egan TJ (2001) Quinoline antimalarials. Expert Opin Drug Discov 11:185-209.

Egan T, Ncokazi KK (2005) Quinoline antimalarials decrease the rate of beta-hematin formation. J Inorg Biochem 99:1532-1539.

Ertl P, Rohde B, Selzer P (2000) Fast calculation of molecular polar surface area as a sum of fragmentbased contributions and its application to the prediction of drug transport properties. J Med Chem 42:3714-3717.

Fidock DA, Rosenthal PJ, Croft SL, Brun R, Nwaka S (2004). Antimalarial drug discovery: Efficacy models for compound screening. Nat Rev Drug Discov 3:509-520.

Finney JD (1978). Probit Analysis: Statistical Treatment of the Sigmoid Response Curve, $3^{\text {rd }}$ ed.; Cambridge University Press: Cambridge, UK, p. 550.

Foley M, Tilley L (1998). Quinoline antimalarials: mechanisms of action and resistance and prospects for new agents. Pharmacol Ther 79:55-87. 
Franck X, Fournet A, Prina E, Mahieux R, Hocquemiller R, Figadère B (2004). Biological evaluation of substituted quinolones. Bioorg Med Chem Lett 14:3635-3638.

Huang B (2009). MetaPocket: A Meta Approach to Improve Protein Ligand Binding Site Prediction. OMICS J. Integr Biol. 3:325-330.

Insuasty B, Ramirez J, Becerra D, Echeverry C, Quiroga J, Abonia R, Robledo SM, Velez ID, Upegui Y, Muñoz JA, Ospina V, Nogueras M, Cobo J (2015). An efficient synthesis of a new caffeinebased chalcones, pyrazolines and pyrazolo[3-4-b][1-4]diazepines as potential antimalarial, antitrypanosomal and antileishmanial agents. Eur J Med Chem 93:401-413

Kaur K, Jain M, Reddy RP, Jain R (2010) Quinolines and structurally related heterocycles as antimalarials. Eur. J. Med. Chem 45:3245-3264.

Keenan M, Chaplin JH (2015). A new era for chagas disease drug discovery? Prog Med Chem 54:185-

230.

Lipinski CA, Lombardo F, Dominy BW, Feeney PJ (1997). Experimental and computational approaches to estimate solubility and permeability in drug discovery and development settings. Adv Drug Deliv Rev 23:3-25.

Liu L, Zhang Y, Wang Y (2005). Phosphine-Free Palladium Acetate Catalyzed Suzuki Reaction in Water. J Org Chem 70:6122-6125.

Lombard MC, N'Da DD, Breytenbach JC, Smith PJ, Lategan CA (2011). Synthesis, in vitro antimalarial and cytotoxicity of artemisinin-aminoquinoline hybrids. Bioorg Med Chem Lett 21:1683-1686.

Londoño F, Cardona W, Alzate F, Cardona F, Vélez ID, Upegui Y, Ospina V, Muñoz JA, Robledo SM (2016). Antiprotozoal activity and cytotoxicity of extracts from Solanum arboreum and S. ovalifolium (Solanaceae). J Med Plants Res 10:100-107.

Lord AM, Mahon MF, Lloyd MD, Threadgill MD (2009). Design, Synthesis, and Evaluation in Vitro of Quinoline-8-carboxamides, a New Class of Poly(adenosine-diphosphate-ribose)polymerase-1 (PARP-1) Inhibitor. J Med Chem 52:868-877.

Ma L, Chen J, Wang X, Liang X, Luo Y, Zhu W, Wang T, Peng M, Li S, Jie S, Peng A, Wei Y, Chen L (2011) Structural modification of honokiol, a biphenyl occurring in magnolia officinalis: the evaluation of honokiol analogues as inhibitors of angiogenesis and for their cytotoxicity and structure-activity relationship. J Med Chem 54:6469-6481 
Menting J, Tilley L, Deady L, Ng K, Simpson R, et al. (1997). The antimalarial drug, chloroquine, interacts with lactate dehydrogenase from Plasmodium falciparum. Mol Biochem Parasitol 88:215224.

Morris GM, Goodshell DS, Halliday RS, Huey R, Hart WE, Belew RK, Olson AJ (1998). Docking Using a Lamarckian Genetic Algorithm and Empirical Binding Free Energy Function. J Comput Chem 19:1639-1662.

Morris GM, Huey R, Lindstrom W, Sanner MF, Belew RK, Goodsell DS, Olson AJ (2009). AutoDock4 and AutoDockTools4: Automated docking with selective receptor flexibility. J Comput Chem 30:2785-2791.

Meunier B (2008) Hybrid molecules with a dual mode of action: dream or reality? Acc Chem Res 41:6977

Nakayama H, Loiseau PM, Bories C, De Ortiz ST, Schinini A, Serna E, Rojas de Arias A, Fakhfakh MA, Franck X, Figadère B, Hocquemiller R, Fournet A (2005). Efficacy of orally administered 2substituted quinolines in experimental murine cutaneous and visceral leishmaniases. Antimicrob. Agents Chemother $49: 4950-4956$

Ncokazi KK, Egan TJ (2005). A colorimetric high-throughput beta-hematin inhibition screening assay for use in the search for antimalarial compounds. Anal Biochem 338:306-319.

Read J, Wilkinson K, Tranter R, Sessions R, Brady R (1999). Chloroquine binds in the cofactor binding site of Plasmodium falciparum lactate dehydrogenase. J Biol Chem 274:10213-10218.

Sajid M, McKerrow JH (2002). Cysteine proteases of parasitic organisms. Mol Biochem Parasitol 120:1-21.

Shaveta, Mishra S, Singh P (2016). Hybrid molecules: The privileged scaffolds for various pharmaceuticals. Eur J Med Chem 124:500-536

Suresh K, Sandhya B, Himanshu G (2009). Biological activities of quinoline derivatives. Mini-Rev Med Chem 9:1648-1654.

Otero E, García E, Palacios G, Yepes LM, Carda M, Agut R, Vélez ID, Cardona WI, Robledo SM (2017). Triclosan-caffeic acid hybrids: Synthesis, leishmanicidal, trypanocidal and cytotoxic activities. Eur J Med Chem 141:73-83.

Otero E, Robledo SM, Díaz S, Carda M, Muñoz D, Paños J, Vélez ID, Cardona W (2014). Synthesis and leishmanicidal activity of cinnamic acid esters: structure-activity relationship. Med Chem Res 23:1378-1386.

Otto HH, Schirmeister T (1997) Cysteine Proteases and Their Inhibitors. Chem Rev 97:133-172.

Palit P, Paira P, Hazra A, Banerjee S, Das Gupta A, Dastidar S, Mondal N (2009) Phase transfer 
catalyzed synthesis of bis-quinolines: antileishmanial activity in experimental visceral leishmaniasis and in vitro antibacterial evaluation. Eur J Med Chem 44:845-853.

Patrick, G.L. 2013. An Introduction to Medicinal Chemistry, fifth ed., Oxford University Press, pp. 114.

Pierson JT, Dumetre A, Hutter S, Delmas F, Laget M, Finet JP, Azas N, Combes S (2010). Synthesis and antiprotozoal activity of 4-arylcoumarins. Eur J Med Chem 45:864-869.

Pulido SA, Muñoz DL, Restrepo AM, Mesa CV, Alzate JF, Vélez ID, Robledo SM (2012).

Improvement of the green fluorescent protein reporter system in Leishmania spp. for the in vitro and in vivo screening of antileishmanial drugs. Acta Trop 122:36-45.

Taylor VM, Cedeño DL, Muñoz DL, Jones MA, Lash TD, Young AM, Constantino MH, Esposito N, Vélez ID, Robledo SM (2011). In vitro and in vivo studies of the utility of dimethyl and diethyl carbaporphyrin ketals in treatment of cutaneous leishmaniasis. Antimicrob Agents Chemother 55:4755-4764.

Tempone A, Melo A, Da Silva P, Brandt C, Martinez F, Borborema A (2005). Synthesis and antileishmanial activities of novel 3-substituted quinolones. Agents chemother 49:1076-1080.

Trott O, Olson AJ (2010). AutoDock Vina: Improving the Speed and Accuracy of Docking with a New Scoring Function, Efficient Optimization, and Multithreading. J Comput Chem 3:455-461.

Veber DF, Johnson SR, Cheng HY, Smith BR, Ward KW, Kopple KD (2002). Molecular properties that influence the oral bioavailability of drug candidates. J Med Chem 45:2615-2623.

Vennerstrom J, Nuzum E, Miller R, Dorn A, Gerena L, et al. (1999). 8-Aminoquinolines active against blood stage Plasmodium falciparum in vitro inhibit hematin polymerization. Antimicrob Agents Chemother 43:598-602.

Vieira NC, Herrenknecht C, Vacus J, Fournet A, Bories C, Figadère B, Espindola LS, Loiseau PM (2008). Selection of the most promising 2-substituted quinoline as antileishmanial candidate for clinical trials Biomed Pharmacother 62:684-689.

World Health Organization (WHO, 2019a) Leishmanisis. https://www.who.int/leishmaniasis/en/. (accessed 04 March 2019)

World Health Organization (WHO, 2019b) Chagas disease (American Trypanosomiasis). http://www.who.int/news-room/fact-sheets/detail/chagasdisease-(american-trypanosomiasis). Accessed 04 March 2019

World Health Organization (WHO, 2018a). Neglected tropical diseases. Available online: http://www.who.int/neglected_diseases/diseases/en/ (accessed on 20 June 2018)

World Health Organization (WHO, 2018b). World Malaria Report 2018. Available online: 
https://www.who.int/malaria/publications/world-malaria-report-2018/report/en/ (accessed on 04 March 2019)

Yang X, Xu G, Tang W (2016). Efficient Synthesis of Chiral Biaryls Via Asymmetric Suzuki-Miyaura Cross-coupling of Ortho-bromo Aryl Triflates. Tetrahedron 72:5178-5183. 